Atmos. Chem. Phys., 18, 16931-16952, 2018

https://doi.org/10.5194/acp-18-16931-2018

(C) Author(s) 2018. This work is distributed under

the Creative Commons Attribution 4.0 License.

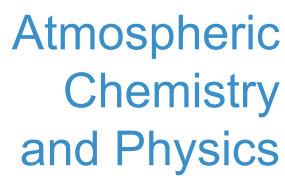

(c) (†)

\title{
Global climate forcing driven by altered BVOC fluxes from 1990 to 2010 land cover change in maritime Southeast Asia
}

\author{
Kandice L. Harper ${ }^{1}$ and Nadine Unger ${ }^{2}$ \\ ${ }^{1}$ School of Forestry \& Environmental Studies, Yale University, New Haven, Connecticut, 06511, USA \\ ${ }^{2}$ College of Engineering, Mathematics and Physical Sciences, University of Exeter, Exeter, EX4 4QJ, UK \\ Correspondence: Kandice L. Harper (harper.kandice@gmail.com) and Nadine Unger (n.unger@exeter.ac.uk)
}

Received: 7 April 2018 - Discussion started: 3 May 2018

Revised: 26 August 2018 - Accepted: 25 September 2018 - Published: 30 November 2018

\begin{abstract}
Over the period of 1990-2010, maritime Southeast Asia experienced large-scale land cover changes, including expansion of high-isoprene-emitting oil palm plantations and contraction of low-isoprene-emitting natural forests. The ModelE2-Yale Interactive terrestrial Biosphere global chemistry-climate model is used to quantify the atmospheric composition changes, and for the first time, the associated radiative forcing induced by the land-coverchange-driven biogenic volatile organic compound (BVOC) emission changes $\left(+6.5 \mathrm{TgC}^{-1}\right.$ isoprene, $-0.5 \mathrm{TgC}^{-1}$ monoterpenes). Regionally, surface-level ozone concentrations largely decreased $(-3.8$ to $+0.8 \mathrm{ppbv})$. The tropical land cover changes occurred in a region of strong convective transport, providing a mechanism for the BVOC perturbations to affect the composition of the upper troposphere. Enhanced concentrations of isoprene and its degradation products are simulated in the upper troposphere, and, on a globalmean basis, land cover change had a stronger impact on ozone in the upper troposphere ( $+0.5 \mathrm{ppbv})$ than in the lower troposphere $(<0.1 \mathrm{ppbv}$ increase $)$. The positive climate forcing from ozone changes $\left(+9.2 \mathrm{~mW} \mathrm{~m}^{-2}\right)$ was partially offset by a negative forcing $\left(-0.8 \mathrm{~mW} \mathrm{~m}^{-2}\right)$ associated with an enhancement in secondary organic aerosol (SOA). The sign of the net forcing is sensitive to uncertainty in the SOA yield from BVOCs. The global-mean ozone forcing per unit of regional oil palm expansion is $+1 \mathrm{~mW} \mathrm{~m}^{-2} \mathrm{Mha}^{-1}$. In light of expected continued expansion of oil palm plantations, regional land cover changes may play an increasingly important role in driving future global ozone radiative forcing.
\end{abstract}

\section{Introduction}

Recent decades have witnessed large-scale land cover and land-use changes on the maritime continent. More than 4.5 Mha of natural forest were cleared in Indonesia alone over 2000-2010, which is a loss of $4.6 \%$ of year 2000 Indonesian natural forest cover (Margono et al., 2014). Increasing demand for palm oil, produced by oil palm trees (Elaeis guineensis), has simultaneously driven widespread expansion of this agro-industrial tree crop (USDA, 2010). Indonesia and Malaysia cumulatively produce $85 \%$ of the current global palm oil supply (USDA, 2017). The amount of land area planted with oil palm in Indonesia and Malaysia increased from 3.5 Mha in 1990 to 13 Mha by 2010 (Gunarso et al., 2013).

Land cover and land-use changes in Southeast Asia perturb the Earth's system in a variety of ways. Deforestation is a significant threat to Southeast Asian biodiversity (Sodhi et al., 2004), and the land-based carbon emissions associated with forest clearing have greatly contributed to Indonesia's status as one of the world's highest emitters of greenhouse gases (GHGs) (FAO, 2014; WRI, 2015). The magnitude of GHG emissions from deforestation is exacerbated by the pervasiveness of carbon-rich peat soils underlying Southeast Asian tropical forests (Carlson et al., 2012; Hooijer et al., 2010; Page et al., 2002; van der Werf et al., 2009). Peat soil drainage (i.e., drying) promotes oxidation of the sequestered carbon (Miettinen et al., 2017) and is often followed by fire clearing, despite the illegality of this practice in Indonesia (Indrarto et al., 2012). Indonesian forest and peat fires have fueled transnational air pollution episodes (Gaveau et al., 2014; Koplitz et al., 2016), potentially causing more than 100000 premature mortalities in 2015 (Koplitz et al., 2016). 
Above-canopy flux measurements taken in Borneo indicate that, compared to the natural forests of maritime Southeast Asia (MSEA), oil palm plantations are much stronger emitters of the biogenic volatile organic compound (BVOC) isoprene $\left(\mathrm{C}_{5} \mathrm{H}_{8}\right)$, with mean midday fluxes about 5 times stronger from oil palm (Langford et al., 2010; Misztal et al., 2011). The simultaneous large-scale contraction of low-isoprene-emitting natural forest area and expansion of high-isoprene-emitting oil palm plantations suggest a landcover-change-driven increase in regional isoprene emissions over recent decades (Silva et al., 2016; Stavrakou et al., 2014). Measurements indicate that the forests of MSEA emit monoterpenes, a class of BVOCs with chemical formula $\mathrm{C}_{10} \mathrm{H}_{16}$, but find negligible monoterpene emissions from oil palm (Langford et al., 2010; Misztal et al., 2011). Both isoprene and monoterpenes are precursors to the short-lived climate pollutant tropospheric ozone (Atkinson and Arey, 2003) and secondary organic aerosols (SOAs) (Carlton et al., 2009; Friedman and Farmer, 2018); as such, perturbations in regional isoprene and monoterpene emissions serve as an additional mechanism by which regional land cover change can affect air quality and climate.

A few studies have used global modeling to investigate the atmospheric composition impacts of Southeast Asian oil palm expansion. Ashworth et al. (2012) analyzed the expected impacts from isoprene emission enhancements associated with the partial replacement of natural forest area with oil palm plantations under a land-use change scenario designed to meet a portion of the projected increase in demand for biofuels in coming years. Warwick et al. (2013) analyzed the impacts from isoprene emission enhancements associated with the total conversion of Borneo from forest to oil palm. Both studies quantified the impacts of the isoprene emission changes first by applying a contemporary $\mathrm{NO}_{x}$ inventory and secondly by assuming increased $\mathrm{NO}_{x}$ emissions near the site of land-use change due to enhanced fertilizer application and increased on-site processing of the palm oil. Based on simulations that apply contemporary $\mathrm{NO}_{x}$ inventories, both studies predict reductions in surface ozone co-located with the isoprene enhancements because the increased VOC serves as a net sink for ozone in the low-NO $\mathrm{N}_{x}$ atmosphere (Ashworth et al., 2012; Warwick et al., 2013). When $\mathrm{NO}_{x}$ emission enhancements occur in concert with the land-usechange-driven isoprene emission enhancements, both studies simulate a net increase in ozone production and a concomitant increase in local surface ozone pollution (Ashworth et al., 2012; Warwick et al., 2013). Ashworth et al. (2012) predict local enhancements in annual-mean surface concentrations as high as $11 \%$ for ozone and $10 \%$ for biogenic SOA (as the maximum change in any grid cell) in response to a $5 \%$ increase in regional isoprene emissions and simultaneous enhancements in local $\mathrm{NO}_{x}$ emissions. Warwick et al. (2013) predict local changes in monthly-mean surface ozone as strong $+70 \%$ when simultaneously increasing $\mathrm{NO}_{x}$ and isoprene emissions. These studies highlight the poten- tial for significant local surface-level pollution impacts from land-use change.

A recent third study quantified the air quality impacts associated with year 2010 oil palm cover relative to an oilpalm-free scenario (Silva et al., 2016). Using the GEOSChem chemical transport model and contemporary inventories for $\mathrm{NO}_{x}$ emissions, Silva et al. (2016) simulate local enhancements in surface pollution as high as $26 \%$ (3-4 ppbv) for ozone and $60 \%$ (about $1 \mu \mathrm{g} \mathrm{m}^{-3}$ ) for SOA. In Kuala Lumpur, Malaysia, the number of days that register ozone levels higher than the limits recommended by the World Health Organization more than doubled due to regional oil palm expansion (56 days based on 2010 oil palm coverage compared to 23 days in the absence of oil palm; Silva et al., 2016), again highlighting the strong impact of Southeast Asian land cover change on surface pollution.

The year 2000, 16-plant functional type (PFT) land cover distribution map that Silva et al. (2016) apply as the no-oilpalm case is designed for global modeling studies and, therefore, lacks information about the distribution of individual species of vegetation. For example, 7.2 Mha of oil palm existed in 2000 in Indonesia, Malaysia, and Papua New Guinea (Gunarso et al., 2013), yet many global vegetation distributions assign these plantations to one or more of a small number of PFTs. Silva et al. (2016) use a $250 \mathrm{~m}$ resolution satellite-based map of year 2010 oil palm plantations to define the contemporary oil palm distribution, and they overlay the oil palm on the palm-free base map, displacing the existing land covers in proportion to their fractional distributions. In reality, the prior land cover of oil palm plantations differs widely by region (Gunarso et al., 2013). Furthermore, the modified land cover distribution from Silva et al. (2016) lacks separate delineations for other pervasive land covers in Southeast Asia, including rubber plantations, which covered at least 6.4 Mha on the maritime continent in 2010 (Gunarso et al., 2013). Rubber trees (Hevea brasiliensis) are very weak emitters of isoprene (Geron et al., 2006; Klinger et al., 2002) but very strong emitters of monoterpenes (Baker et al., 2005; Klinger et al., 2002), which are important SOA precursors (Jokinen et al., 2015). Thus, while the study by Silva et al. (2016) provides evidence of significant surface pollution changes induced by oil palm expansion in Southeast Asia, it provides an incomplete picture of the impact of historical land cover change on atmospheric composition.

This small set of studies focuses on the atmospheric composition impacts induced by altered BVOC emissions from Southeast Asian oil palm expansion, all finding that the downwind impacts are smaller in magnitude than the local impacts near the site of land conversion and isoprene emission changes (Ashworth et al., 2012; Silva et al., 2016; Warwick et al., 2013). Ashworth et al. (2012) speculated a small global forcing impact from the increased isoprene emissions in their land-use change scenario, based on the small simulated global changes in the tropospheric burdens of ozone and the hydroxyl radical $(\mathrm{OH})$. However, no study has di- 
rectly quantified the global radiative impacts associated with the induced changes in atmospheric composition.

Isoprene perturbations in the tropics may have a particularly powerful impact on longwave radiative forcing (Unger, 2014) because the strong vertical mixing prevalent in the tropics provides a mechanism for surface pollution perturbations to impact ozone concentrations in the upper troposphere (Thompson et al., 1997), where, on a per-molecule basis, ozone changes induce the strongest climate impact due to the thermal contrast with the surface (Lacis et al., 1990). In response to isoprene emission enhancements associated with total conversion of vegetated land to oil palm on the island of Borneo, Warwick et al. (2013) simulate a $20 \%$ increase in ozone at $500 \mathrm{hPa}$ over Borneo and a $20 \%$ increase in peroxyacetyl nitrate (PAN) at $500 \mathrm{hPa}$ downwind of Borneo over the Pacific Ocean. PAN is an organic nitrate that can undergo long-range transport before releasing its reactive $\mathrm{NO}_{x}$ moiety (Moxim et al., 1996), providing a means for ozone formation in remote environments (Kotchenruther et al., 2001). The results of Warwick et al. (2013) suggest that regional isoprene emission changes have the capacity to alter ozone concentrations in the free troposphere and, therefore, induce a radiative forcing.

This study uses the ModelE2-Yale Interactive Terrestrial Biosphere (ModelE2-YIBs) global chemistry-climate model, in conjunction with multiple observational datasets, to quantify the global atmospheric composition changes and, for the first time, the concomitant radiative forcings associated with BVOC emission changes from 1990 to 2010 land cover change in MSEA. The calculations presented here consider changes in emissions of both isoprene and monoterpenes. The applied regional land cover changes are derived from a Landsat-based classification (Gunarso et al., 2013) and account for changes in eight land covers that are prevalent in MSEA, including high-monoterpene-emitting rubber trees and high-isoprene-emitting oil palm trees.

\section{Data and methods}

\subsection{ModelE2-YIBs description}

Atmosphere-only simulations employ the NASA GISS ModelE2-YIBs global chemistry-climate model. The YIBs model (Yue and Unger, 2015) is a land surface model embedded in the NASA GISS ModelE2 global chemistry-climate model (Schmidt et al., 2014). The model features $2^{\circ}$ latitude $\times 2.5^{\circ}$ longitude horizontal resolution, 40 vertical layers (surface to $0.1 \mathrm{hPa}$ ), and a physical and chemical time step of $30 \mathrm{~min}$.

The chemical mechanism includes 156 reactions involving 51 chemical species with full coupling of tropospheric and stratospheric chemistry (Schmidt et al., 2014; Shindell et al., 2006). The troposphere features $\mathrm{NO}_{x}-\mathrm{O}_{x}-\mathrm{HO}_{x}-\mathrm{CO}-$ $\mathrm{CH}_{4}$ chemistry; an explicit representation of isoprene; and a lumped hydrocarbon scheme involving terpenes, peroxyacyl nitrates (PANs), alkyl nitrates, aldehydes, alkenes, and alkanes. The representation of hydrocarbons generally follows Houweling et al. (1998), which is originally derived from the Carbon Bond Mechanism IV (Gery et al., 1989) and the Regional Atmospheric Chemistry Mechanism (RACM; Stockwell et al., 1997), but includes several modifications aimed at representing the wide range of chemical conditions found in Earth's atmosphere, such as the addition of reactions important in low- $\mathrm{NO}_{x}$ conditions, including representation of organic peroxy radical chemistry under low- $\mathrm{NO}_{x}$ conditions and introduction of organic nitrate chemistry. Shindell et al. (2013) describe in detail the recent updates to the tropospheric chemistry scheme, including the incorporation of acetone chemistry (Houweling et al., 1998) and the addition of terpene oxidation (Tsigaridis and Kanakidou, 2007). SOA formation is driven by $\mathrm{NO}_{x}$-dependent oxidation of emissions of isoprene, monoterpenes, and other reactive VOCs following a volatility-based two-product scheme (Tsigaridis and Kanakidou, 2007). The formation of secondary inorganic aerosols, including sulfate (Bell et al., 2005; Koch et al., 2006) and nitrate (Bauer et al., 2007a), depend on both modeled oxidant levels and the availability of source gases. Primary aerosol types include dust (which provides a surface for heterogeneous chemistry; Bauer and Koch, 2005; Bauer et al., 2007b), black carbon, organic carbon, and sea salt (Koch et al., 2006). Stratospheric chemistry, introduced to the chemical mechanism by Shindell et al. (2006), includes nitrous oxide $\left(\mathrm{N}_{2} \mathrm{O}\right)$ and halogen (bromine and chlorine) chemistry. Recent updates to stratospheric chemistry are summarized by Shindell et al. (2013) and include changes in the representations of polar stratospheric cloud formation (Hanson and Mauersberger, 1988) and heterogeneous hydrolysis of $\mathrm{N}_{2} \mathrm{O}_{5}$ on sulfate (Hallquist et al., 2003; Kane et al., 2001). Photolysis rate calculations follow the Fast-J2 scheme of Bian and Prather (2002). At each 30 min time step, the simulated distributions of clouds, ozone, and aerosols are passed to the photolysis code, providing a mechanism for simulated changes in aerosols to impact atmospheric chemistry through modification of photolysis rates (Bian et al., 2003).

Global annual-mean mixing ratios are prescribed for the well-mixed greenhouse gases carbon dioxide $\left(\mathrm{CO}_{2}\right)$, methane $\left(\mathrm{CH}_{4}\right)$, nitrous oxide $\left(\mathrm{N}_{2} \mathrm{O}\right)$, and chlorofluorocarbons (CFCs) (Meinshausen et al., 2011; Riahi et al., 2007). Prescribed monthly anthropogenic and biomass burning emissions of reactive gas and primary aerosol species follow the MACCity emissions pathway (Angiola et al., 2010; Granier et al., 2011) for all years, except for 2010, when the interpolated ACCMIP-RCP8.5 dataset (Heil and Schultz, 2014) is applied for biomass burning emissions (as MACCity biomass burning emissions are available only through 2008). MACCity biomass burning emissions were built from the ACCMIP (Lamarque et al., 2010), REanalysis of the TROpospheric chemical composition (RETRO; Schultz et 
al., 2008), and Global Fire Emissions Database (GFED-v2; van der Werf et al., 2006) datasets (Granier et al., 2011). The interpolated ACCMIP-RCP8.5 emissions were created using simple temporal interpolation of the ACCMIP and RCP8.5 datasets (Heil and Schultz, 2014). Identical surface maps and emission factors were applied in the creation of both the MACCity and interpolated ACCMIP-RCP 8.5 biomass burning emissions datasets (Heil and Schultz, 2014). The model dynamically calculates climate-sensitive emissions of reactive compounds for a number of natural sources. These emission sectors, with their primary driving meteorological variables, include: lightning $\mathrm{NO}_{x}$ (moist convection; Price and Rind, 1992; Price et al., 1997), soil $\mathrm{NO}_{x}$ (precipitation and temperature; Yienger and Levy II, 1995), dust (wind speed; Miller et al., 2006), sea salt particles (wind speed; Koch et al., 2006), marine dimethyl sulfide (wind speed; Koch et al., 2006), and the BVOCs isoprene (radiation, temperature, and soil moisture; Arneth et al., 2007; Unger et al., 2013) and monoterpenes (temperature; Lathière et al., 2006), which are described in more detail below.

Leaf-level gas exchange in ModelE2 (Collatz et al., 1991) couples the Farquhar-von Caemmerer kinetic model of photosynthetic $\mathrm{CO}_{2}$ uptake (Farquhar et al., 1980; Farquhar and von Caemmerer, 1982) to the Ball-Berry model of stomatal conductance (Ball et al., 1987). The environmental inputs used to drive the vegetation biophysics, isoprene emissions, and monoterpene emissions are the values simulated by the general circulation model. The standard YIBs vegetation comprises eight plant functional types: C3-grassland, C4-grassland, crop, deciduous broadleaf forest, evergreen broadleaf forest, evergreen needleleaf forest, shrubland, and tundra. The model code was modified to include four additional land cover types: (1) oil palm plantations, (2) rubber tree plantations, (3) other tree plantations, and (4) dipterocarp evergreen broadleaf forest. Relative to the forests of the Amazon, the tropical forests of MSEA contain a larger proportion of evergreen dipterocarp forests (Hewitt et al., 2010). The dipterocarp evergreen broadleaf forest PFT was added to account for the comparatively lower isoprene emission capacity (Langford et al., 2010; Stavrakou et al., 2014) of the natural forests of MSEA. In each model grid cell, an individual canopy is simulated for each PFT. The canopy radiative transfer scheme divides each canopy into a flexible number of vertical layers (generally 2-16). In each layer, sunlit leaves use direct photosynthetically active radiation (PAR) for leaflevel photosynthesis, while shaded leaves use diffuse PAR (Spitters et al., 1986).

YIBs features a process-based biochemical model of isoprene emission in which the rate of isoprene production dynamically depends on the electron-transport-limited rate of photosynthetic carbon assimilation (Arneth et al., 2007; Unger et al., 2013). For each PFT, the isoprene emission rate depends linearly on the fraction of electrons available to undergo isoprene synthesis, the calculation of which requires prescription of a PFT-specific leaf-level isoprene basal emis- sion rate (BER) at standard conditions. The leaf-level isoprene emission rate additionally depends on the atmospheric $\mathrm{CO}_{2}$ concentration and the simulated canopy temperature and PAR. The ability of the model to simulate isoprene emissions has been evaluated extensively against multiple abovecanopy flux datasets from tropical and temperate ecosystems (Unger et al., 2013). The model simulated the local flux magnitude within a factor of 2 at nine specific measurement sites, some of which correspond to short (weeks-long) measurement campaigns (Unger et al., 2013). Temperaturedependent leaf-level monoterpene emissions, functionally $\alpha$ pinene, likewise vary by ecosystem type, similarly through prescription of PFT-specific basal emission rates (Guenther et al., 1995; Lathière et al., 2006). Recent work suggests that tropical monoterpene emissions exhibit both a light and temperature dependency (Guenther et al. 2012; Jardine et al., $2015,2017)$ that is not included in the emission algorithm here but may be explored in future work.

Aerosol and gas-phase chemistry are fully coupled, and the chemical mechanism is fully coupled to the climate modules (e.g., radiation and dynamics). All simulations apply ozone and aerosol climatologies to the radiation code (Schmidt et al., 2014), but simulated changes in ozone and aerosols can impact calculated photolysis rates. In this study, aerosols do not affect cloud properties. Observationbased, monthly-varying, 5-year-average sea surface temperature and sea ice fields are prescribed according to the Hadley Centre Sea Ice and Sea Surface Temperature dataset (Rayner et al., 2003).

ModelE2 has previously undergone extensive, rigorous validation of simulated present-day tropospheric and stratospheric chemical composition, circulation, and ozone forcing using multiple observational datasets (Shindell et al., 2006, 2013). Shindell et al. (2013) compared simulated monthly zonal-mean total column ozone to that from observations (2000-2010 means) from the Total Ozone Mapping Spectrometer and the Ozone Monitoring Instrument (McPeters et al., 2008), finding that the simulated zonal-mean total column ozone in the tropics shows little bias $(<5 \%)$ against measurements for each month, and, in the Northern Hemisphere middle and high latitudes, biases are smaller in the summer months $(<10 \%)$ than in the winter months (around $15 \%-20 \%$ ). Shindell et al. (2013) find only a small negative bias $\left(-0.016 \mathrm{~W} \mathrm{~m}^{-2}\right)$ in the present-day global-average radiative impact of modeled tropospheric ozone relative to TES-derived tropospheric ozone. They note that the strongest biases in ozone concentrations in ModelE2 are generally located in regions where ozone exhibits little effect on radiation (Shindell et al., 2013). More recently, Harper et al. (2018) compared annual-mean ozone concentrations simulated by ModelE2 (representative of year 2005) with an ozonesonde climatology based on measurements taken over 1995-2011 (Tilmes et al., 2012), finding lower model biases at higher pressures (e.g., $+2.6 \%$ at $200 \mathrm{hPa}$ compared to $+16.9 \%$ at $800 \mathrm{hPa})$. 
A number of uncertainties exist related to both isoprene oxidation chemistry and SOA formation. For example, field measurements, including one campaign over Borneo (Stone et al., 2011), indicate that $\mathrm{OH}$ concentrations over the pristine tropical rainforest are much higher than predicted by known isoprene chemistry (Lelieveld et al., 2008; Martinez et al., 2010; Stone et al., 2011). A number of OH-recycling mechanisms associated with isoprene oxidation have been proposed (e.g., da Silva et al., 2010; Lelieveld et al., 2008; Paulot et al., 2009; Peeters et al., 2009). Other researchers have argued that the high measured $\mathrm{OH}$ concentrations may be an artifact of the type of instrumentation employed, which results in an artificial inflation of the measured concentrations (Mao et al., 2012). No $\mathrm{OH}$ recycling is applied in the $\mathrm{OH}$-initiated isoprene oxidation pathway in the chemical mechanism of ModelE2-YIBs because of the significant uncertainties associated with this aspect of isoprene chemistry. Importantly, Warwick et al. (2013) found that inclusion of $\mathrm{OH}$ recycling had little impact on the magnitude or distribution of surface ozone changes induced by biogenic emission changes from the total conversion of Bornean tropical forest to oil palm plantations. However, some studies suggest that the simulation of ozone and other oxidants is sensitive to the isoprene chemical mechanism that is applied (e.g., Archibald et al., 2010; Emmerson and Evans, 2009; Knote et al., 2015). Furthermore, the appropriateness of using $\alpha$-pinene to represent monoterpenes as a single lumped species in global modeling is an active area of research. Friedman and Farmer (2018) find order-of-magnitude differences in SOA yields for $\mathrm{OH}$ oxidation of different monoterpene species, but a clear explanation based on isomer structure remains largely elusive. While Friedman and Farmer (2018) find that the magnitude of the SOA yield from $\alpha$-pinene is in the "mid-range" of the yields among the analyzed monoterpene species, other studies have shown that this may not be the case for other oxidation pathways (e.g., Draper et al., 2015). The appropriateness of using the two-product scheme for SOA production in global models is likewise an open question (e.g., Tsigaridis et al., 2014) and is discussed in more detail in Sect. 4. Future work would benefit from an exploration of the impact on radiative forcing induced through application of different mechanisms of (1) isoprene photooxidation and (2) SOA formation (e.g., Surratt et al., 2010; Zhang et al., 2018).

\subsection{Vegetation datasets}

The land cover distributions for MSEA that are applied to the simulations are built from the results of a visual classification of Landsat images that additionally used highresolution Google Earth images and other datasets (e.g., maps of roads) to aid image interpretation (Gunarso et al., 2013). The Gunarso et al. (2013) classification encompasses 22 land cover types in $30 \mathrm{~m} \times 30 \mathrm{~m}$ pixels for the principal oil-palm-producing regions of maritime Southeast Asia Papua New Guinea, Malaysia (Peninsular Malaysia, Sabah, and Sarawak), and three regions of Indonesia (Kalimantan, Papua, and Sumatra) - nominally for 1990, 2000, 2005, and 2010. The year 2010 Gunarso et al. (2013) dataset relies on some 2009 Landsat images due to intense cloudiness in 2010. As Gunarso et al. (2013) did not perform the classification for Papua New Guinea for 2005, the areal coverage for the grid cells in this region for this year is estimated here through linear interpolation of the year 2000 and 2010 Gunarso et al. (2013) datasets. The Gunarso et al. (2013) classification for 1990 in Indonesia is likewise incomplete; in this dataset, the pixels classified for 1990 are principally those that are oil palm in 1990 or eventually become oil palm. The Gunarso et al. (2013) classification for 2000 was applied to all Indonesian pixels that were not classified in 1990. As such, the 1990 Indonesian land cover map that is applied to the ModelE2YIBs simulations is a hybrid of 1990 and 2000 data. While Indonesian oil palm cover in 1990 is accurate within the limits of the classification methodology, Indonesian forest cover is presumably lower in the hybrid dataset than it was in reality in 1990, which means that Indonesian forest loss over the period of 1990-2010 is likely underestimated in this study.

Using the $30 \mathrm{~m} \times 30 \mathrm{~m}$ pixels from the Gunarso et al. (2013) analysis, including the estimates described above for 2005 in Papua New Guinea and 1990 in Indonesia, the areal coverage of each of the 22 land cover types was quantified for each $2^{\circ}$ latitude $\times 2.5^{\circ}$ longitude ModelE2-YIBs grid cell and distributed on the ModelE2-YIBs land surface map. Seventeen of the twenty-two land cover types of the Gunarso et al. (2013) dataset were aggregated into a set of eight cover types (Table S1 in the Supplement). Four of the cover types in the aggregated set (shrubland, crops, C4-grassland, and bare ground) belong to the standard set of YIBs cover types, while the other four cover types (dipterocarp forest, oil palm plantations, rubber plantations, and other tree plantations) are new cover types added to YIBs for this study. The aggregation and subsequent calculation of fractional areal coverage of land for these eight cover types ignored five minor land cover types from the Gunarso et al. (2013) classification: water bodies, coastal fish ponds, mining areas, settlements, and pixels that are unclassified due to clouds.

In the land cover dataset applied to YIBs, 1990-2010 forest loss is likely underestimated because (1) the 1990 Indonesian forest extent is partially derived from the Gunarso et al. (2013) year 2000 map due to unclassified land area in the Gunarso et al. (2013) year 1990 map and (2) deforestation in this dataset represents complete removal of a forest patch and does not account for forest degradation. The ModelE2-YIBs dipterocarp forest PFT combines the "disturbed" and "undisturbed" forest classes from the Gunarso et al. (2013) analysis (Table S1); thus, reduction in forest basal area from the partial logging of a forest does not register as forest loss in the YIBs dataset as long as the affected patch still meets the Gunarso et al. (2013) classification criteria for the disturbed forest class. An analysis of the leaf area index (LAI) of rainforest plots in Central Sulawesi, Indone- 
sia, under different land use regimes found that disturbance of the forest by selective logging reduced the LAI below the $6.2 \mathrm{~m}^{2}$ (leaf) $\mathrm{m}^{-2}$ (ground) value measured for the undisturbed natural forest (Dietz et al., 2007). Removal of "smalldiameter" trees reduced LAI to $5.3 \mathrm{~m}^{2} \mathrm{~m}^{-2}$, while removal of "large-diameter" trees reduced LAI to $5.0 \mathrm{~m}^{2} \mathrm{~m}^{-2}$ (Dietz et al., 2007). Thus, disturbed (selectively logged) forests maintain a high LAI, suggesting that combining the disturbed and undisturbed forest classes into a single PFT is well justified for the purposes of this study.

The Landsat-based YIBs-compatible land cover distributions are applied to the 57 model grid cells covering Peninsular Malaysia, Sumatra, Borneo, and New Guinea (Fig. S1). The simulations apply nonzero areal extents of the four new land cover types only in MSEA. Table 1 shows, for the new land cover types, the assigned physical parameters (including LAI and vegetation height), photosynthetic parameters, and leaf-level basal emission rates of isoprene and monoterpenes.

The static land cover distribution applied to the rest of the world is the year 2000 land cover distribution developed for the Community Land Model (CLM; Oleson et al., 2010) using multiple satellite datasets, including retrievals from both MODIS (Hansen et al., 2003) and AVHRR (DeFries et al., 2000). The 16-PFT data were aggregated into the standard set of eight YIBs PFTs (Yue and Unger, 2015). Gridded PFTspecific LAI and vegetation height parameters are prescribed. For the rest-of-world vegetation, prescribed LAIs are derived from the CLM (Oleson et al., 2010); and prescribed heights are the output of a 140-year ModelE2-YIBs simulation (Yue and Unger, 2015) that simulated dynamic carbon allocation, used the same CLM land cover distribution described here, and was forced with year 2000 meteorology from the WFDEI (WATCH Forcing Data methodology applied to ERA-Interim data; Weedon et al., 2014) dataset.

Table 2 shows the areal extents of YIBs land covers in MSEA for 1990, 2005, and 2010. Figure S1 in the Supplement shows the regional land cover distribution for 1990 . Over 1990-2010, 11.3 Mha of natural rainforest was lost ( $-8 \%$ relative to 1990). Forest loss was widespread on Borneo, Sumatra, and Peninsular Malaysia (Fig. S2). Contraction of rubber plantations $(-1.4 \mathrm{Mha})$ was primarily confined to Sumatra and Peninsular Malaysia. The highisoprene-emitting oil palm class experienced the largest absolute increase in areal extent over the study era $(+9.6 \mathrm{Mha}$, $+267 \%$ ). Widespread expansion occurred on Sumatra, Borneo, and Peninsular Malaysia.

\subsection{Simulation configurations}

Table 3 summarizes the configurations of nine global chemistry-climate simulations. Two principal time-slice simulations - 2010land_base and 1990land_base - are used to diagnose the global-mean radiative perturbation associated with the atmospheric composition changes induced by 1990-2010 land cover change in MSEA. The two simula- tions differ only in terms of the year of the applied maritime Southeast Asian land cover distribution, which is indicated in the simulation names. The regional land cover changes are imposed on a background climate and atmosphere representative of year 2010; that is, both the 2010 land cover distribution in the perturbation simulation and the 1990 land cover distribution in the control simulation are exposed to the climate state, atmospheric $\mathrm{CO}_{2}$ concentration, and background atmosphere representative of year 2010. The presentday rest-of-world land cover distribution is identical for all simulations. All simulations were run for 13 years, and averages over the final 10 years of output were used for analysis. The impact of 1990-2010 maritime Southeast Asian land cover change, denoted $\triangle \mathrm{LC}$, on atmospheric composition and radiative balance is diagnosed as 2010land_base minus 1990land_base (Table 4). Seven additional simulations (Tables 3 and 4) probe the sensitivity of the radiative forcing results to (1) the applied background atmosphere; (2) the degree of regional land cover change; (3) the magnitude of the isoprene BER assigned to the oil palm plantation PFT; and (4) the magnitude of the isoprene BER assigned to the dipterocarp forest PFT.

Isoprene production in ModelE2-YIBs is calculated as a semi-mechanistic function of photosynthetic carbon assimilation (Unger et al., 2013). Isoprene emissions are sensitive to simulated changes in the parameters that affect photosynthesis, including the background climate state (e.g., temperature, PAR, and soil moisture) and the atmospheric $\mathrm{CO}_{2}$ concentration. Simulated monoterpene emissions are likewise sensitive to temperature shifts (Lathière et al., 2006). Following emission, the atmospheric processing of isoprene and monoterpenes is influenced by the background atmospheric composition; for example, the availability of $\mathrm{NO}_{x}$ affects the VOC-driven production of both ozone (Sillman, 1999) and SOA (Tsigaridis and Kanakidou, 2007). The calculation 2010land_1990atm minus 1990land_1990atm, denoted $\Delta$ LC-1990atm, is designed to test the influence of the prescribed background state upon which the maritime Southeast Asian land cover changes are imposed (Table 4). Relative to the main set of simulations probing Southeast Asian land cover change (i.e., $\Delta \mathrm{LC}$ ), the $\Delta \mathrm{LC}-1990 \mathrm{~atm}$ simulations prescribe identical changes in Southeast Asian land cover, but impose the changes on a background state representative of year 1990 rather than year 2010 (Table 3). The different background states can lead to different isopreneand monoterpene-driven impacts on ozone and SOA concentrations from the identical prescribed land cover changes by influencing (1) the magnitude and distribution of the isoprene and monoterpene emission changes associated with the land cover changes and (2) the atmospheric processing of the emitted isoprene and monoterpenes.

A third pair of simulations (2005land_base minus 1990land_base, denoted $\Delta$ LC-2005) quantifies the global impacts of 1990-2005 maritime Southeast Asian land cover change (Table 4). Because the land cover distributions in both 
Table 1. Physical and photosynthetic parameters and isoprene and monoterpene basal emission rates assigned to four new land cover types in the ModelE2-YIBs source code. Plts is plantations.

\begin{tabular}{lrrrr}
\hline Parameter & Dipterocarp forest $^{\mathrm{a}}$ & Oil palm plts $^{\mathrm{b}}$ & Rubber plts $^{\mathrm{c}}$ & Other tree plts $^{\mathrm{d}}$ \\
\hline$V_{\mathrm{cmax} 25}\left(\mu \mathrm{mol} \mathrm{CO}_{2} \mathrm{~m}^{-2} \mathrm{~s}^{-1}\right)$ & 40 & 42 & 44 & 40 \\
$I_{\mathrm{S}}\left(\mu \mathrm{gCg}{ }^{-1}\left(\right.\right.$ leaf dry weight $\left.\mathrm{h}^{-1}\right)$ & 2 & 153 & 0.17 & 2 \\
$M_{\mathrm{S}}\left(\mu \mathrm{ggC} \mathrm{g}^{-1}\left(\right.\right.$ leaf dry weight $\left.\mathrm{h}^{-1}\right)$ & 0.6 & 0 & 25 & 0.6 \\
$\mathrm{SLA}\left(\mathrm{m}^{2}\left(\right.\right.$ leaf $\mathrm{kg}^{-1}$ (leaf)) & 9.9 & 10.5 & 9.9 & 9.9 \\
PAR absorptance & 0.9 & 0.93 & 0.9 & 0.9 \\
Height $(\mathrm{m})$ & 35 & 12 & 18 & 18 \\
LAI $\left(\mathrm{m}^{2}\right.$ (leaf) $\mathrm{m}^{-2}$ (ground) & 6 & 6 & 6 & 5.3 \\
\hline
\end{tabular}

Parameters: (1) $V_{\mathrm{cmax} 25}$ : maximum photosynthetic capacity at $25^{\circ} \mathrm{C}$; (2) $I_{\mathrm{S}}$ : leaf-level isoprene basal emission rate (BER) at standard conditions of incident photosynthetically active radiation (PAR; $1000 \mu \mathrm{mol}$ photons $\mathrm{m}^{-2} \mathrm{~s}^{-1}$ ) and leaf temperature $\left(30^{\circ} \mathrm{C}\right)$; (3) $M_{\mathrm{S}}$ : leaf-level monoterpene BER at standard conditions of incident PAR $\left(1000 \mu\right.$ mol photons $\left.\mathrm{m}^{-2} \mathrm{~s}^{-1}\right)$ and leaf temperature $\left(30^{\circ} \mathrm{C}\right)$; (4) SLA: specific leaf area; (5) PAR absorptance: the fraction of PAR photons incident on the leaf that are absorbed by the leaf; (6) vegetation height; and (7) leaf area index (LAI).

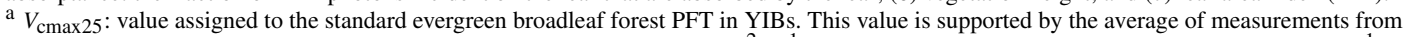
five common tree species in the forest of Sulawesi, Indonesia $\left(38.4 \mu \mathrm{mol} \mathrm{m}{ }^{-2} \mathrm{~s}^{-1}\right.$; Rakkibu, 2008). IS : Upper limit of the BER $\left(<2 \mu \mathrm{gC} \mathrm{g}{ }^{-1} \mathrm{~h}^{-1}\right)$ reported for the species Dipterocarpus obtusifolius (Geron et al., 2006). Three additional tree species in the Dipterocarpaceae family are likewise reported to have low leaf-level isoprene emission rates, where low indicates an emission rate on the order of $0.1 \mathrm{\mu gC} \mathrm{g}^{-1} \mathrm{~h}^{-1}$ (actual numerical rates are not provided; Klinger et al., 2002). $M_{\mathrm{S}}$ : calculated as the mean of the measured leaf-level emission rates for 11 dipterocarp species (Llusia et al., 2014). Height: measurement from a natural forest plot in Malaysian Borneo (Fowler et al., 2011), within the range reported by Dietz et al. (2007) for natural forest plots. LAI: Measurement from natural forest plot in Malaysian Borneo (Fowler et al., 2011). Close to the LAI of $6.2 \mathrm{~m}^{2} \mathrm{~m}^{-2}$ estimated for undisturbed forest stands by Dietz et al. (2007). SLA and PAR absorptance: values assigned to the standard evergreen broadleaf forest PFT in YIBs. ${ }^{b} V_{\text {cmax 25: }}$ corresponds to mature (12-year-old) plantations (Meijide et al., 2017). I $I_{S}$ : Cronn and Nutmagul, 1982; Kesselmeier and Staudt, 1999. $M_{\mathrm{S}}$ : measured emissions for six different monoterpenes (Geron et al., 2006). SLA: average of two measurements (Fan et al., 2015; Legros et al., 2009). PAR absorptance: for measurements of mature leaves (Ritchie and Runcie, 2014). Height and LAI: measurements from 12-year-old commercial plantation in Malaysian Borneo (Misztal et al., 2011). ${ }^{\mathrm{c}} V_{\mathrm{cmax} 25}$ : Kositsup et al., 2009. $I_{\mathrm{S}}$ : Geron et al., 2006; Klinger et al., 2002. $M_{\mathrm{S}}$ : Baker et al., 2005; Klinger et al., 2002. SLA and PAR absorptance: values assigned to the standard evergreen broadleaf forest PFT in YIBs. Height: mean height of rubber trees measured in 49 stands in Peninsular Malaysia (Suratman et al., 2004). LAI: rubber trees are evergreen trees in the humid tropics (Li et al., 2016). Assigned LAI measured for a mature oil palm plantation in Malaysian Borneo (Misztal et al., 2011). ${ }^{\mathrm{d}}$ Description: this PFT is a combination of the timber plantation and mixed tree crop and agroforest cover types from the Gunarso et al. (2013) land cover classification scheme that is used to build the maritime Southeast Asian land cover distribution maps that are applied to the ModelE2-YIBs simulations. Typical species grown on timber plantations include Gmelina sp., Paraserianthes falcataria, and Acacia mangium (Gunarso et al., 2013). Southeast Asian agroforest plots can contain a diverse array of vegetation, including oil palm, rubber trees, herbaceous crops, and many other tree species used as cash or subsistence crops (e.g., fruit and timber trees) (Scales and Marsden, 2008). Many agroforest plots in Southeast Asia maintain forest-like structural characteristics, despite the fact that they are cultivated, rather than natural, systems (Scales and Marsden, 2008). $V_{\mathrm{cmax} 25}$ : value assigned to both the evergreen broadleaf forest and crop classes in YIBs. $I_{\mathrm{S}}$ : Same as dipterocarp forest PFT. Low-isoprene-emitting rubber trees are prevalent in Indonesian agroforest systems (Scales and Marsden, 2008), warranting a low BER for this agroforest-containing PFT. The average $I_{\mathrm{S}}\left(4.7 \mu \mathrm{gC} \mathrm{g} \mathrm{g}^{-1} \mathrm{~h}^{-1}\right.$ ) based on two common timber species - Acacia mangium (Klinger et al., 2002) and Gmelina arborea (Singh et al., 2014) - is similar in magnitude to the $I_{S}$ for the dipterocarp forest PFT, providing further justification for assignment of a low $I_{\mathrm{S}} . M_{\mathrm{S}}$ : same as dipterocarp forest PFT. Similar $M_{\mathrm{S}}$ is reported for Acacia mangium $\left(0.66 \mu \mathrm{gC} \mathrm{g}^{-1} \mathrm{~h}^{-1}\right.$; Klinger et al., 2002), SLA and PAR absorptance: values assigned to the standard evergreen broadleaf forest PFT in YIBs. Height: reported height measured for plots of an agroforest (Dietz et al., 2007) and a timber plantation (Krisnawati et al., 2011). LAI: mean LAI reported for three agroforest plots in Central Sulawesi, Indonesia (Dietz et al., 2007). The timber plantation class from Gunarso et al. (2013) has a partially open canopy, indicating a lower LAI than for the natural forest PFT.

Table 2. Areal extents (Mha) of eight YIBs land cover types in maritime Southeast Asia. Extents encompass only the 57 grid cells that apply the land cover distributions derived from the Gunarso et al. (2013) analysis. The changes in areal extent (in Mha) relative to 1990 are listed in parentheses for 2005 and 2010.

\begin{tabular}{lrrr}
\hline YIBs land cover & 1990 & 2005 & 2010 \\
\hline Shrubland & 29.7 & $30.5(+0.8)$ & $30.8(+1.1)$ \\
Crops & 10.6 & $11.3(+0.7)$ & $13.1(+2.6)$ \\
C4-grassland & 3.2 & $2.9(-0.3)$ & $2.9(-0.3)$ \\
Bare & 2.8 & $3.3(+0.5)$ & $3.6(+0.8)$ \\
Oil palm plantations & 3.6 & $9.8(+6.3)$ & $13.2(+9.6)$ \\
Rubber plantations & 7.8 & $6.7(-1.1)$ & $6.4(-1.4)$ \\
Other tree plantations & 14.0 & $13.7(-0.3)$ & $12.9(-1.1)$ \\
Dipterocarp rainforest & 140.6 & $134.0(-6.7)$ & $129.3(-11.3)$ \\
\hline
\end{tabular}
in 2010 that would have been expected had land cover remained static after 2005. Because land cover in MSEA is rapidly changing and there is uncertainty associated with the classification procedures used to create the land cover maps (Sect. 2.2), such information provides insight into the degree to which the land-cover-change-driven forcing depends on the exact land cover distribution that is applied.

The fourth pair of simulations (2010land_OPber minus 1990land_OPber, denoted $\triangle$ LC-OPber) probes the sensitivity of the land-cover-change-induced impacts on atmospheric composition and climate to the magnitude of the isoprene BER applied to oil palm plantations (Table 4). Halving the isoprene BER applied to oil palm plantations brings the simulated $24 \mathrm{~h}$ mean isoprene emission rate from oil palm plantations for 2010 close to the rate measured using abovecanopy fluxes (described in Sect. 3.3). Similarly, the fifth pair background conditions, $\Delta \mathrm{LC}-2005$ represents the impacts 
Table 3. Simulation configurations.

\begin{tabular}{lrrll}
\hline Simulation & $\begin{array}{r}\text { Southeast Asian } \\
\text { land cover }\end{array}$ & $\begin{array}{r}\text { Other boundary } \\
\text { conditions }\end{array}$ & $\begin{array}{l}\text { Isoprene BER } \\
\text { for oil palm }\end{array}$ & $\begin{array}{l}\text { Isoprene BER } \\
\text { for dipterocarp forest }\end{array}$ \\
\hline 2010land_base & 2010 & 2010 & Measured & Measured \\
1990land_base & 1990 & 2010 & Measured & Measured \\
2010land_1990atm & 2010 & 1990 & Measured & Measured \\
1990land_1990atm & 1990 & 1990 & Measured & Measured \\
2005land_base & 2005 & 2010 & Measured & Measured \\
2010land_OPber & 2010 & 2010 & $1 / 2 \times$ measured & Measured \\
1990land_OPber & 1990 & 2010 & $1 / 2 \times$ measured & Measured \\
2010land_DPTber & 2010 & 2010 & Measured & $12 \times$ measured \\
1990land_DPTber & 1990 & 2010 & Measured & $12 \times$ measured \\
\hline
\end{tabular}

\footnotetext{
a The non-land-cover variable boundary conditions include: well-mixed greenhouse gas $\left(\mathrm{CH}_{4}, \mathrm{CO}_{2}, \mathrm{~N}_{2} \mathrm{O}\right.$, and halocarbon) mixing ratios applied to model radiation; $\mathrm{CH}_{4}, \mathrm{~N}_{2} \mathrm{O}$, and halocarbon mixing ratios applied to atmospheric chemistry; $\mathrm{CO}_{2}$ mixing ratio applied to the land biosphere; reactive emissions of carbon monoxide $(\mathrm{CO})$, ammonia $\left(\mathrm{NH}_{3}\right), \mathrm{NO}_{x}$, sulfur dioxide $\left(\mathrm{SO}_{2}\right)$, non-methane volatile organic compounds (NMVOCs), black carbon (BC), and organic carbon (OC) from anthropogenic and biomass burning sectors; sea surface temperatures; and sea ice fields. Monthly sea ice and sea surface temperature fields are 5-year averages centered on the simulation year.
}

of simulations (2010land_DPTber minus 1990land_DPTber, denoted $\triangle$ LC-DPTber) probes the sensitivity of the radiative forcing from 1990 to 2010 land cover change to the magnitude of the isoprene BER applied to dipterocarp forests. In this sensitivity analysis, the dipterocarp forest isoprene BER is increased by a factor of 12 , making it equivalent to the isoprene BER assigned to the standard evergreen broadleaf forest PFT in YIBs (Table 1).

\section{Results and discussion}

\subsection{Gross primary production and isoprene and monoterpene emissions}

Simulated global gross primary production (GPP) for 2010 is $124 \mathrm{PgCy}^{-1}$ (simulation 2010land_base), which almost precisely matches an estimate derived from flux-tower measurements that is representative of 1998-2005: $123 \pm$ $8 \mathrm{PgCy}^{-1}$ (mean \pm 1 standard deviation; Beer et al., 2010). The simulated 1990 global GPP of $108 \mathrm{PgCy}^{-1}$ (simulation 1990land_1990atm) is outside of the 1 standard deviation range of the observation-based mean, but falls within the $95 \%$ confidence interval $\left(102-135 \mathrm{PgCy}^{-1}\right.$; Beer et al., 2010). Guenther et al. (2012) collated contemporary global annual BVOC emission estimates from the literature, finding ranges of $309-706 \mathrm{TgC}^{-1}$ for isoprene and $26-156 \mathrm{TgC}^{-1}$ for monoterpenes. The model estimates for $1990\left(325 \mathrm{TgC}^{-1}\right.$ isoprene and $90 \mathrm{TgC}^{-1}$ monoterpenes for simulation 1990land_1990atm) and $2010\left(363 \mathrm{TgC}^{-1}\right.$ isoprene and $77 \mathrm{TgCy}^{-1}$ monoterpenes) fall within these ranges. Using the same process-based, leaf-level isoprene production algorithm employed in ModelE2-YIBs, although driven with different forcing datasets, Hantson et al. (2017) predict contemporary isoprene emissions $\left(385 \mathrm{TgCy}^{-1}\right.$; 1971-2000 mean) that are 18\% higher than those predicted here for 1990 and only $6 \%$ higher than those predicted here for 2010.

In MSEA, 2010 isoprene emission rates are generally higher on Sumatra, Peninsular Malaysia, and Borneo than on the island of New Guinea (Fig. S3), which maintains high areal coverage of low-isoprene-emitting dipterocarp rainforests. Rubber plantations contributed $56 \%\left(1.6 \mathrm{TgC}^{-1}\right)$ of the regional monoterpene emissions in 2010, while oil palm $\left(8.8 \mathrm{TgC}^{-1}\right)$ and shrubs $\left(5.8 \mathrm{TgC}^{-1}\right)$ dominated regional isoprene emissions ( $55 \%$ and $36 \%$, respectively). The low-isoprene-emitting dipterocarp rainforests, which covered $61 \%$ of the region's land surface in 2010, were responsible for only $8 \%$ of regional isoprene emissions. The strong contributions made by rubber and oil palm plantations to the regional monoterpene and isoprene budgets, respectively, underscore the importance of explicitly accounting for these land covers in regional land use and land cover change analyses.

Regional 1990-2010 land cover change induced a negligible decrease in regional GPP $\left(-0.1 \mathrm{PgCy}^{-1}\right)$, which is principally attributed to an increase from oil palm $\left(+0.3 \mathrm{PgC}^{-1}\right)$ and a decrease from dipterocarp rainforests $\left(-0.4 \mathrm{PgC}^{-1}\right)$. Regional land cover change induced annual emissions changes of $+6.5 \mathrm{TgCy}^{-1}$ isoprene and $-0.5 \mathrm{TgC}^{-1}$ monoterpenes. The land-cover-change-driven net increase in regional isoprene emissions is almost entirely due to expansion of industrial oil palm plantations $\left(+6.4 \mathrm{TgC}^{-1},+271 \%\right.$ relative to 1990 oil palm isoprene emissions). Regional isoprene emissions from shrubs increased by $4.2 \%\left(+0.2 \mathrm{TgCy}^{-1}\right)$, associated with a $3.7 \%$ increase in shrubland. The large loss of dipterocarp rainforest had little impact on isoprene emissions $\left(-0.1 \mathrm{TgC}^{-1}\right)$, as this PFT is a weak isoprene emitter. Contraction of rubber plantation extent was largely responsible for the reduction in monoterpene emissions $\left(-0.4 \mathrm{TgC}^{-1}\right)$. 
Table 4. Calculation methodology. MSEA LCC is maritime Southeast Asian land cover change. The control simulation varies between pairs of simulations.

\begin{tabular}{lll}
\hline Identifier & Calculation & Description \\
\hline$\Delta$ LC & 2010land_base-1990land_base & $\begin{array}{l}\text { Impact of 1990-2010 MSEA LCC imposed } \\
\text { on 2010 background atmosphere }\end{array}$ \\
\hline$\Delta$ LC-1990atm & 2010land_1990atm-1990land_1990atm & $\begin{array}{l}\text { Impact of 1990-2010 MSEA LCC imposed } \\
\text { on 1990 background atmosphere }\end{array}$ \\
\hline$\Delta$ LC-2005 & 2005land_base-1990land_base & $\begin{array}{l}\text { Impact of 1990-2005 MSEA LCC imposed } \\
\text { on 2010 background atmosphere }\end{array}$ \\
\hline$\Delta$ LC-OPber & 2010land_OPber-1990land_OPber & $\begin{array}{l}\text { Impact of 1990-2010 MSEA LCC imposed } \\
\text { on 2010 background atmosphere using halved } \\
\text { isoprene BER for oil palm plantations }\end{array}$ \\
\hline$\Delta$ LC-DPTber & 2010land_DPTber-1990land_DPTber & $\begin{array}{l}\text { Impact of 1990-2010 MSEA LCC imposed } \\
\text { on 2010 background atmosphere using enhanced } \\
(12 \times) \text { isoprene BER for dipterocarp forests }\end{array}$ \\
\hline
\end{tabular}

\subsection{Atmospheric composition}

Low surface ozone concentrations are simulated for the pristine atmospheres of the tropical forests. In the Southeast Asia study region in 2010 (2010land_base), the less disturbed landscapes of Borneo and New Guinea exhibit lower surface ozone concentrations than the comparatively more industrialized regions of Sumatra and Peninsular Malaysia (Fig. S4). Considering only the grid cells in the 57-grid-cell study area that are majority $(>50 \%)$ forest by area, simulated annualmean surface ozone concentrations in 2010 are $9.0 \mathrm{ppbv}$ in New Guinea $(n=10)$ and 9.5 ppbv in Borneo $(n=7)$. Considering only the grid cells that are $>85 \%$ forest by area, simulated ozone concentrations are $7.8 \mathrm{ppbv}$ in New Guinea $(n=4)$ and $7.2 \mathrm{ppbv}$ in Borneo $(n=2)$. Measurements at a rainforest site in Malaysian Borneo in 2008 found daytime surface-level ozone mixing ratios of 5-8 ppbv (Hewitt et al., 2010), providing support for the low ozone concentrations simulated over the highly forested regions of the study area.

1990-2010 land cover change in MSEA drove a reduction in annual-mean surface ozone concentrations over Borneo, Peninsular Malaysia, and Sumatra (Fig. 1). Negligible changes occurred over New Guinea. Isoprene oxidation is more implicated in ozone production and loss rather than SOA formation (whereas monoterpenes are more implicated in SOA formation). Regionally, small surface ozone enhancements are simulated over the marine environment, with maximum enhancements occurring over the ocean to the west of Sumatra. Because this region exhibits low surface ozone concentrations, the small absolute changes $(-3.8$ to $+0.8 \mathrm{ppbv}$ ) translate into comparatively large relative changes $(-18.3 \%$ to $+4.3 \%)$.

Simulated reductions in surface ozone largely occur in the regions of enhanced isoprene emissions, specifically Peninsular Malaysia, Sumatra, and Borneo (Fig. S5). Surface ozone reductions occurring in response to enhanced VOC emissions in low- $\mathrm{NO}_{x}$ conditions are associated with an increase in the relative importance of ozone destruction reactions (e.g., direct reaction of the VOC with ozone) (Ashworth et al., 2012; Sillman, 1999). $\mathrm{NO}_{x}$ surface emissions in the analysis region were, on average, $0.036 \mathrm{mgN} \mathrm{m}^{-2} \mathrm{~h}^{-1}$ in 2010. Based on atmospheric chemical modeling in conjunction with aircraft and ground measurements in Borneo, $\mathrm{NO}_{x}$ fluxes for 2008 were inferred as $0.009 \mathrm{mgN} \mathrm{m}^{-2} \mathrm{~h}^{-1}$ over a rainforest site and $0.019 \mathrm{mgN} \mathrm{m}^{-2} \mathrm{~h}^{-1}$ over an oil palm plantation (Hewitt et al., 2009). The applied $\mathrm{NO}_{x}$ emissions are slightly higher than, but the same order of magnitude as, the observation-based inferred fluxes, providing support for the "NO ${ }_{x}$-sensitive regime" (Sillman, 1999) that is modeled in this study.

Previous studies have shown that the sign and strength of the regional surface ozone response to increased isoprene strongly depend on availability of $\mathrm{NO}_{x}$ (Ashworth et al., 2012; Silva et al., 2016; Warwick et al., 2013). When applying contemporary $\mathrm{NO}_{x}$ emissions from published inventories, both Warwick et al. (2013) and Ashworth et al. (2012) simulated local surface ozone reductions in response to increased isoprene emissions from regional oil palm expansion. The Warwick et al. (2013) study was an idealized simulation that carpeted Borneo in oil palm, while the Ashworth et al. (2012) study applied future projections of oil palm expansion for biofuel production. Both studies found that increasing the $\mathrm{NO}_{x}$ emissions in the region of land conversion (to account for enhanced fertilizer application and industrial processing of the oil palm) enhanced surface ozone concentrations (Ashworth et al., 2012; Warwick et al., 2013). In a study focused on estimating the air quality impacts associated with 2010 oil palm cover compared to a no-oil-palm landscape, Silva et al. (2016) simulated increased surface ozone concentrations over much of the region. They found 
(a) $\Delta$ surface ozone (Southeast Asia)

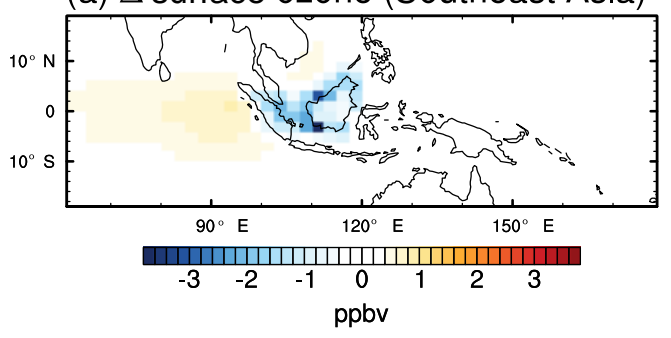

(c) $\Delta$ ozone at $335 \mathrm{hPa}$

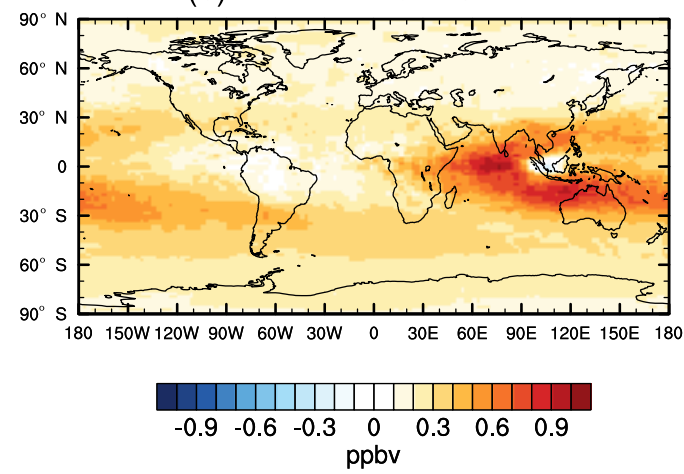

(b) $\Delta$ surface ozone (global)

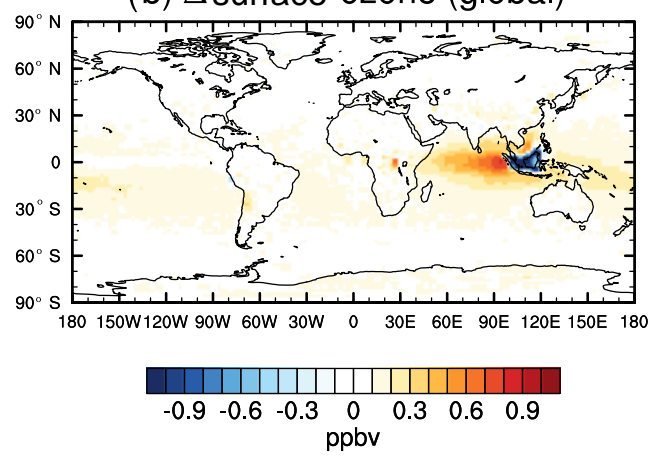

(d) $\Delta$ ozone profile

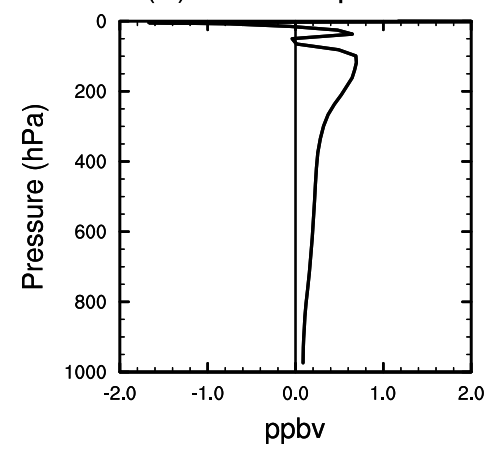

Figure 1. Changes in annual-mean ozone mixing ratio (ppbv) due to 1990-2010 maritime Southeast Asian land cover change: (a) Southeast Asian surface-level ozone; (b) global surface-level ozone; (c) tropospheric ozone at $335 \mathrm{hPa}$; and (d) global-mean ozone profile.

that some low- $\mathrm{NO}_{x}$ regions (e.g., parts of Borneo) exhibited surface ozone reductions in response to increased isoprene emissions (Silva et al., 2016). The differences in the simulated impacts on regional surface ozone between this study and the Silva et al. (2016) study are likely due to the magnitude of the applied regional $\mathrm{NO}_{x}$ emissions.

The simulated changes in atmospheric composition might be a response not only to altered isoprene and monoterpene emissions, but also to changes in the deposition of atmospheric species induced by changes in leaf density (Wong et al., 2018) or related changes, such as surface roughness, stomatal conductance, and evapotranspiration, that are affected by the applied changes in land cover distribution. Here, the relative changes in regional ozone deposition rates $(-19.7 \%$ to $+4.3 \%)$ are similar to the relative changes in regional surface-level ozone concentrations $(-18.3 \%$ to $+4.3 \%$ ) from 1990-2010 regional land cover change, in part because the ozone deposition rate depends on the atmospheric concentration change. While increased isoprene emission leading to increased isoprene ozonolysis drives ozone losses near the surface, a formal quantitative attribution analysis disentangling the relative roles of emission and deposition changes requires further complex sensitivity simulations that are beyond the scope of this analysis. In their analysis of Southeast Asian oil palm expansion, Silva et al. (2016) used sensitivity studies to determine that the induced BVOC emission changes, rather than altered deposition rates from LAI changes, were almost exclusively responsible for the simulated surface ozone changes.

While the strongest impacts of regional land cover change on annual-mean surface ozone are confined to Southeast Asia, weak long-range enhancements are simulated, particularly over the tropical ocean $(<1$ ppbv over Indian Ocean, $<0.5$ ppbv elsewhere) (Fig. 1). Enhanced isoprene oxidation drives an increase in the formation of alkyl nitrates, which are $\mathrm{NO}_{x}$ reservoirs. Alkyl nitrates sequester reactive $\mathrm{NO}_{x}$ upon formation and can undergo long-range transport, eventually releasing the $\mathrm{NO}_{x}$ far from the source region (Atherton, 1989). Thus, alkyl nitrate perturbations provide a mechanism for ozone perturbations to occur far from the site of the hydrocarbon emission change (Hollaway et al., 2017), here, resulting in ozone enhancements over the tropical ocean.

With decreasing atmospheric pressure, the long-range impact on ozone spreads beyond the tropics and generally grows in magnitude (Fig. 1). The global-mean ozone enhancement increases in magnitude as altitude increases from the surface to $\sim 100 \mathrm{hPa}$ (Fig. 1). Considering the troposphere, the global-mean ozone enhancement from regional 
land cover change is on the order of $0.5 \mathrm{ppbv}$ in the upper troposphere (e.g., at $237 \mathrm{hPa}$ ), compared to $<0.1 \mathrm{ppbv}$ in the lower troposphere (at pressures $>875 \mathrm{hPa}$ ). The maximum relative change in the global-mean ozone mixing ratio is $+0.6 \%$, occurring at $160 \mathrm{hPa}$. While enhanced alkyl nitrate formation can likewise play a role in the free tropospheric ozone changes (as for surface ozone), additional mechanisms of ozone change (including in situ production from transported isoprene and its degradation products) are also implicated, as described below.

The land-cover-change-driven maritime Southeast Asian isoprene perturbations occur in a region of deep convection (Folkins et al., 1997). The co-location of emission perturbations and strong vertical transport results in changes in chemical composition throughout the atmosphere (Fig. 2). The strongest zonal-mean enhancements in isoprene occur in the lower troposphere at pressures $>850 \mathrm{hPa}$ (maximum $=$ $+88 \%$, occurring near the equator). As a doubly unsaturated hydrocarbon, isoprene is highly reactive in the oxidizing atmosphere. Most of the increased isoprene is rapidly oxidized in the lower atmosphere, yet some is transported to the middle and upper troposphere by strong tropical convection. The isoprene enhancements are generally weaker in the middle and upper troposphere relative to the lower troposphere; considering pressures $<850 \mathrm{hPa}$, the relative change peaks at $+37 \%$ at $139 \mathrm{hPa}, 5^{\circ} \mathrm{N}$.

Upper-tropospheric enhancements in isoprene have been predicted by global model simulations (Collins et al., 1999) and have been observed in convective events over Canada (Apel et al., 2012). When transport-driven isoprene enhancements occur in the presence of lightning $\mathrm{NO}_{x}$ emissions, upper-tropospheric ozone enhancements are predicted (Apel et al., 2012). Lightning $\mathrm{NO}_{x}$ is prevalent in the tropical upper troposphere (Beirle et al., 2010; Boersma et al., 2005), and annual-mean upper-tropospheric ozone enhancements are simulated in this study. The largest zonal-mean tropospheric ozone changes induced by regional land cover change occur in the tropical near-tropopause region (Fig. 2), which is particularly important from a climate perspective because the climate impact of a unit of tropospheric ozone change increases with altitude and is maximized at the tropopause (Lacis et al., 1990). The maximum zonal-mean tropospheric ozone enhancement is $+1.4 \mathrm{ppbv}\left(99 \mathrm{hPa}, 5^{\circ} \mathrm{S}\right)$.

Formaldehyde (HCHO) is a high-yield oxidation product of isoprene (Wolfe et al., 2016). In response to maritime Southeast Asian land cover change, enhanced zonalmean formaldehyde mixing ratios are simulated along the equator from the surface to the upper troposphere (Fig. 2). The strongest changes occur in the lower troposphere, with weaker enhancements in the middle and upper troposphere. Increased upper-tropospheric formaldehyde can result from direct convection of formaldehyde or from in situ production following convection of its precursors (e.g., isoprene).

Laboratory measurements suggest that, in high- $\mathrm{NO}_{x}$ conditions, $60 \%$ of isoprene-derived carbon in the atmosphere eventually becomes CO (Miyoshi et al., 1994). Zonalmean $\mathrm{CO}$ enhancements are simulated for most of the atmosphere, with peak upper-tropospheric enhancements $>$ $1 \mathrm{ppbv}$ (Fig. 2). CO is itself an ozone precursor, contributing to the simulated ozone enhancements. The isoprene and formaldehyde change signatures suggest vertical transport in the absence of significant horizontal mixing, which is expected given their short lifetimes on the order of hours. With a lifetime on the order of a few months, $\mathrm{CO}$ can undergo significant mixing before being destroyed, explaining why its perturbations are more widely distributed throughout the atmosphere.

In OH-initiated oxidation of isoprene in the presence of $\mathrm{NO}_{x}$, isoprene nitrates can form from direct reaction of isoprene peroxy radicals with nitric oxide (NO) (Lockwood et al., 2010). In ModelE2-YIBs, $15 \%$ of isoprene $+\mathrm{OH}$ reactions in the presence of $\mathrm{NO}_{x}$ produce a primary alkyl nitrate molecule (alkyl nitrates can also be formed from other oxidation pathways) (Shindell et al., 2003). Peak zonal-mean alkyl nitrate enhancements are simulated as $+19 \%$ in the lower troposphere, $+5 \%$ in the upper troposphere, and $+4 \%$ in the stratosphere (Fig. 2). Cold temperatures extend the lifetime of alkyl nitrates in the upper troposphere (Apel et al., 2012), resulting in alkyl nitrate perturbations that are more strongly mixed throughout the upper troposphere and lower stratosphere relative to the lower and middle troposphere (Fig. 2). Sequestration of the reactive $\mathrm{NO}_{x}$ into the alkyl nitrates contributes to the simulated reduction in $\mathrm{NO}_{x}$ mixing ratios in the upper troposphere and lower stratosphere (Fig. 2). Enhanced alkyl nitrate formation is also responsible for surface ozone enhancements over the tropical ocean, as described above.

The land-cover-change-driven isoprene perturbations likewise impact the concentrations of the $\mathrm{HO}_{x}\left(\mathrm{OH}+\mathrm{HO}_{2}\right)$ radical family. Collins et al. (1999) found that enhanced convection of isoprene and its oxidation products to the upper troposphere enhances $\mathrm{HO}_{x}$ production, principally through increased photolysis of the oxidation products, including formaldehyde. Here, annual zonal-mean $\mathrm{HO}_{x}$ concentrations are enhanced in the tropics from the surface to the upper troposphere in a pattern that largely mimics that of the formaldehyde perturbations (Fig. 2).

Cumulatively, these changes demonstrate that land cover change in MSEA has the capacity to alter the chemical composition of the upper troposphere. Increased isoprene emissions in a region of deep convection results in enhanced upper-tropospheric concentrations of isoprene and its degradation products, which contribute to enhanced ozone mixing ratios in the climatically important near-tropopause region.

\subsection{Radiative forcing}

Instantaneous radiative forcings are reported as mean \pm 1 standard deviation, calculated over 10 model years. The uncertainties represent internal model variability. In this 

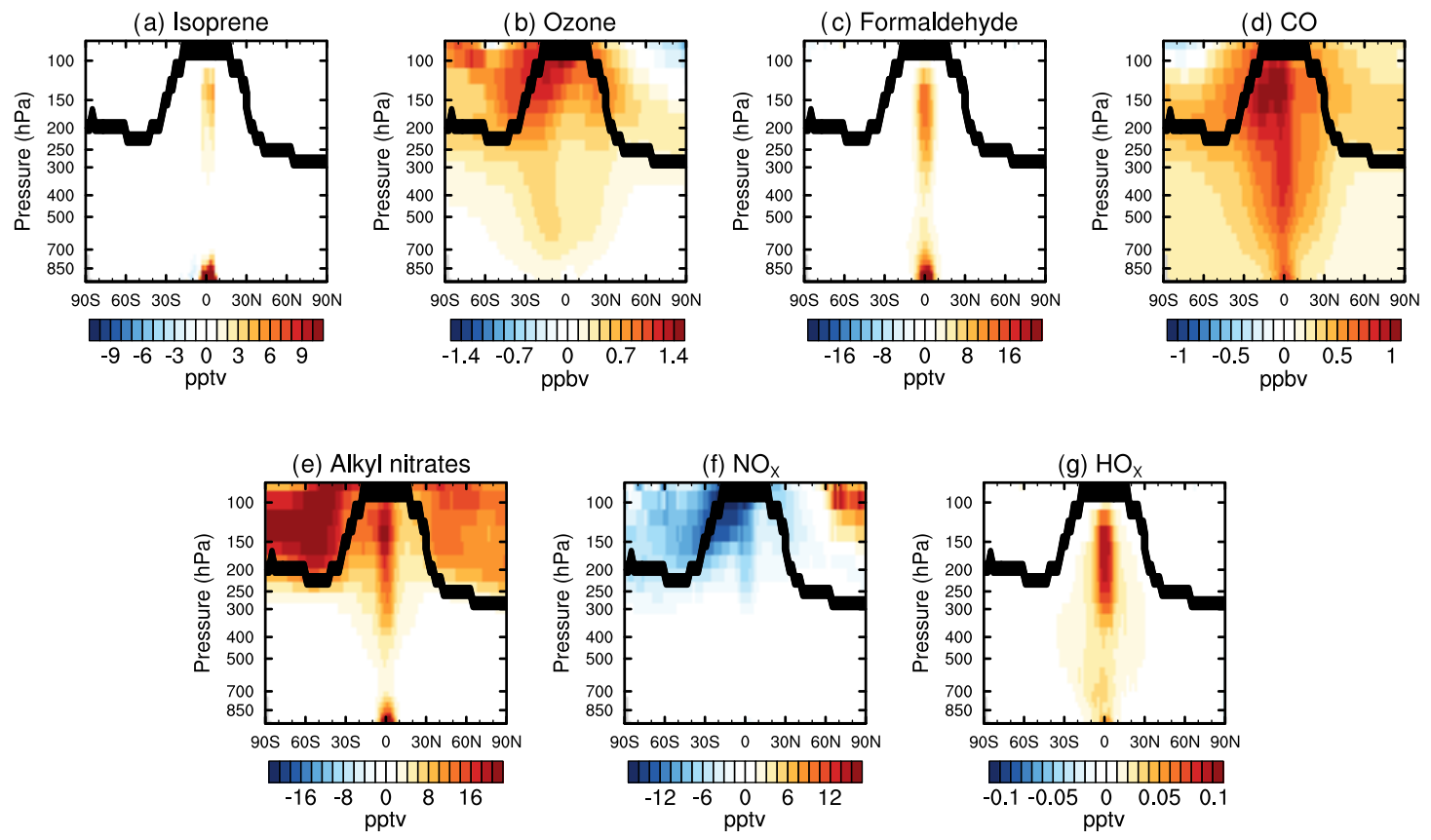

Figure 2. Changes in annual zonal-mean concentrations of (a) isoprene, (b) ozone, (c) formaldehyde, (d) $\mathrm{CO}$, (e) alkyl nitrates, (f) $\mathrm{NO}_{x}$, and (g) $\mathrm{HO}_{x}$ from 1990-2010 maritime Southeast Asian land cover change. Black traces indicate tropopause location.

study, the quantified radiative perturbations arise specifically from ozone and aerosol changes driven by regional land cover change. Only direct aerosol-radiation interactions are considered for aerosols.

The atmospheric composition changes induced by 1990 2010 maritime Southeast Asian land cover change resulted in a positive annual global-mean radiative forcing of $+8.4 \pm$ $0.7 \mathrm{~mW} \mathrm{~m}^{-2}$ (Table 5). The global ozone perturbation induced a positive forcing of $+9.2 \pm 0.7 \mathrm{~mW} \mathrm{~m}^{-2}$, offset only slightly by a negative forcing $\left(-0.8 \pm 0.1 \mathrm{~mW} \mathrm{~m}^{-2}\right)$ induced by a $1.4 \%$ enhancement $(+6.5 \mathrm{Gg})$ in the global burden of largely reflective SOA particles. (The regional change in SOA is plotted in Fig. S6). The ozone radiative forcing distribution (Fig. 3; range: -10.4 to $+37.6 \mathrm{~mW} \mathrm{~m}^{-2}$ ) largely reflects the pattern of mid- and upper-tropospheric ozone changes (Fig. 1), such that the magnitude of the positive forcing largely tracks the magnitude of the ozone enhancement, particularly in the tropics. On a per-molecule basis, enhancements in ozone have a stronger impact on longwave forcing the nearer they are to the tropopause (Lacis et al., 1990), which explains the close association between the patterns of upper tropospheric ozone changes and the ozone forcing magnitude. The strongest ozone forcings occur over the tropical Indian Ocean.

The sensitivity studies investigate the uncertainty in the forcing magnitude. For all five drivers, the negative SOA forcing is much smaller in magnitude than the positive ozone forcing, resulting in a total forcing that is positive in sign (Table 5). This consistency provides confidence in the positive

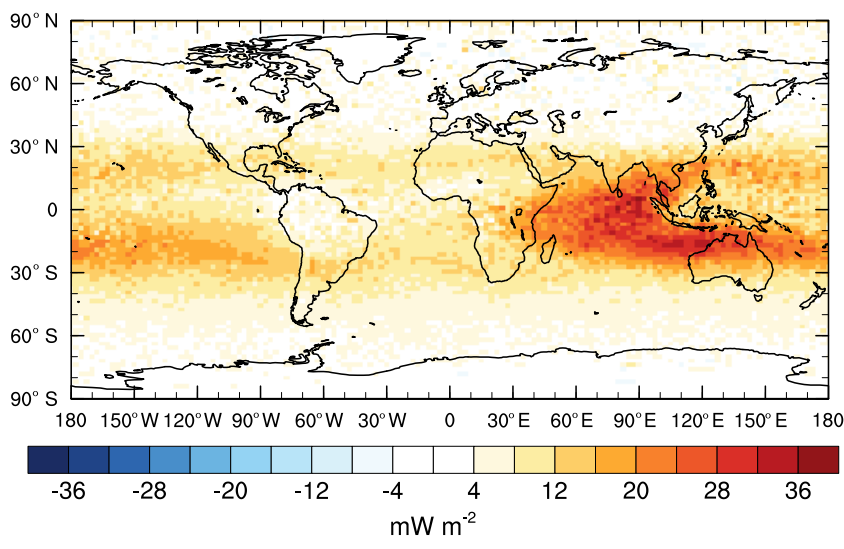

Figure 3. Annual-mean ozone forcing $\left(\mathrm{mW} \mathrm{m}^{-2}\right)$ due to 1990 2010 maritime Southeast Asian land cover change.

sign of the total forcing induced by land-cover-change-driven perturbations in atmospheric composition. Of all of the sensitivity analyses, $\triangle \mathrm{LC}$-OPber results in the smallest magnitude forcing for both ozone and SOA (Table 5). The oil palm isoprene BER applied to the simulations used for the $\triangle \mathrm{LC}$ OPber calculations was half the magnitude of the published leaf-level BER (Table 1) applied to the simulations used for the $\triangle \mathrm{LC}$ calculations.

Application of the halved BER brings the simulated $24 \mathrm{~h}$ mean isoprene emission rate from oil palm plantations for $2010\left(3.8 \mathrm{mgC} \mathrm{m}^{-2} \mathrm{~h}^{-1}\right.$ in simulation 2010land_OPber vs. $7.6 \mathrm{mgC} \mathrm{m}^{-2} \mathrm{~h}^{-1}$ in simulation 2010land_base) in line with 
Table 5. Global annual-mean radiative forcing $\left(\mathrm{mW} \mathrm{m}^{-2}\right)$ from changes in atmospheric composition induced by maritime Southeast Asian land cover change. Mean \pm 1 standard deviation, calculated over 10 model years.

\begin{tabular}{lrrrrr}
\hline $\begin{array}{l}\text { Radiative forcing } \\
\left(\mathrm{mW} \mathrm{m}^{-2}\right)\end{array}$ & $\Delta \mathrm{LC}$ & $\Delta$ LC-1990atm & $\Delta$ LC-OPber & $\Delta$ LC-DPTber & $\Delta$ LC-2005 \\
\hline Ozone & $+9.2 \pm 0.7$ & $+8.8 \pm 0.7$ & $+4.3 \pm 0.7$ & $+6.2 \pm 0.7$ & $+6.3 \pm 0.7$ \\
SOA & $-0.8 \pm 0.1$ & $-0.6 \pm 0.1$ & $-0.3 \pm 0.1$ & $-0.5 \pm 0.1$ & $-0.5 \pm 0.2$ \\
\hline Total & $+8.4 \pm 0.7$ & $+8.2 \pm 0.7$ & $+4.0 \pm 0.7$ & $+5.7 \pm 0.7$ & $+5.8 \pm 0.6$ \\
\hline
\end{tabular}

the rate measured in 2008 above an industrial oil palm estate in Malaysian Borneo $\left(3.9 \mathrm{mgC} \mathrm{m}^{-2} \mathrm{~h}^{-1}\right.$; Misztal et al., 2011). However, the measured flux, based on a short 12-day measurement window, is sensitive to the prevailing meteorological conditions (Misztal et al., 2011). Misztal et al. (2011) note that the isoprene flux would have been twice as high under the meteorological conditions (PAR and temperature) that they measured during the period prior to initiation of their flux measurements; such a rate would match the rate calculated for the simulation that applied the published leaflevel BER (2010land_base). Thus, the isoprene flux measurements provide confidence in the order of magnitude of the simulated isoprene emissions from oil palm plantations. The ozone forcing calculated using the $\Delta$ LC-OPber sensitivity analysis $\left(+4.0 \mathrm{~mW} \mathrm{~m}^{-2}\right)$ is considered to be the lower bound of a best estimate of the global-mean ozone forcing from maritime Southeast Asian land cover change.

Increasing the isoprene BER for the dipterocarp forest PFT by a factor of 12 increases the magnitude of the 1990-2010 isoprene emissions reduction associated with the large contraction in areal cover of this PFT $\left(-1.3 \mathrm{TgC}^{-1}\right.$ for $\Delta \mathrm{LC}$-DPTber vs. $-0.1 \mathrm{TgCy}^{-1}$ for $\left.\Delta \mathrm{LC}\right)$. This decreases the magnitude of the net enhancement in isoprene emissions from total land cover change in the study region $\left(+5.3 \mathrm{TgC}^{-1}\right.$ for $\Delta$ LC-DPTber vs. $+6.5 \mathrm{TgC}^{-1}$ for $\Delta \mathrm{LC})$. The positive ozone forcing for $\Delta \mathrm{LC}$-DPTber is still two-thirds of the magnitude of the ozone forcing for $\Delta \mathrm{LC}$ (Table 5), despite the factor-of-12 enhancement in the assigned dipterocarp forest BER. Using the 2010 simulation that applies the dipterocarp forest isoprene BER taken from leaf-level measurements (2010land_base simulation), the simulated $24 \mathrm{~h}$ mean emission rate of isoprene from maritime Southeast Asian rainforests for $2010\left(0.12 \mathrm{mgC} \mathrm{m}^{-2} \mathrm{~h}^{-1}\right)$ is one-third of the eddy-covariance-based measured emission rate for 2008 from a natural forest in Malaysian Borneo $\left(0.35 \mathrm{mgC} \mathrm{m}^{-2} \mathrm{~h}^{-1}\right.$; Langford et al., 2010). The measured flux was shown to be highly sensitive to the meteorological conditions (e.g., wet season flux is $0.22 \mathrm{mgC} \mathrm{m}^{-2} \mathrm{~h}^{-1}$, dry season flux is $0.47 \mathrm{mgC} \mathrm{m}^{-2} \mathrm{~h}^{-1}$; Langford et al., 2010). The results of $\triangle$ LC-DPTber suggest that increasing the dipterocarp forest BER by a factor of roughly 3 (to force alignment of the simulated isoprene emission magnitude with the 2008 measurements) would have little impact on the total forcing magnitude (because increasing the BER by a factor of 12 had only a slight impact on the forcing). Because the isoprene emissions capacity of oil palms is so strong relative to that of the dipterocarp forest, the isoprene emissions changes from 1990 to 2010 regional land cover change are dominated by the oil palm PFT. The total land-cover-change-driven forcing is more sensitive to uncertainty in the magnitude of the oil palm BER than to uncertainty in the magnitude of the dipterocarp forest BER. The limited importance of the isoprene emission changes from dipterocarp forest loss additionally indicates that the potential underestimate in forest loss in the land cover dataset applied to these simulations (Sect. 2.2) is unlikely to have a strong impact on the magnitude of the quantified forcing.

The total forcing associated with 1990-2005 land cover change ( $\triangle$ LC-2005) is $69 \%$ of the forcing associated with 1990-2010 land cover change ( $\Delta \mathrm{LC})$, indicating that $31 \%$ of the total 1990-2010 forcing is associated with land cover change that occurred over the short 2005-2010 period. The $\Delta$ LC-2005 analysis investigates the sensitivity of the simulated forcing to uncertainty in the land cover distribution maps. The ozone forcing is tightly linked to changes in the areal cover of oil palm, and the global-mean ozone forcing per Mha of regional expansion of oil palm plantations is $+1 \mathrm{~mW} \mathrm{~m}^{-2} \mathrm{Mha}^{-1}$ (the same value is obtained regardless of whether the output from the $\Delta \mathrm{LC}$ analysis or the $\Delta \mathrm{LC}$ 2005 analysis is used).

The land cover maps used in this study are based on the land cover classification of Gunarso et al. (2013), which identified large ( $>1000 \mathrm{ha}$ ) patches of oil palm cover. Estimates suggest that around $40 \%$ of Indonesian oil palm area in 2010 (and $26 \%$ in 1990) was associated with smallholders, in contrast to state-owned or private companies (Indonesian Ministry of Agriculture, 2017; Lee et al., 2014). In Malaysia, the smallholder estimate is likewise around $40 \%$ (Vermeulen and Goad, 2006, citing the Malaysian Palm Oil Board). Smallholder plantings are either schemed (contiguous with a larger estate) or independent (Vermeulen and Goad, 2006). In the latter case, plantations are typically on the order of 2-50 ha (Vermeulen and Goad, 2006), far smaller than the patches identified by the Gunarso et al. (2013) analysis. Gunarso et al. (2013) note that it is unknown what proportion of the total smallholder plantation area is excluded 
from the total oil palm areal cover quantified in their analysis. Nonetheless, it is likely that the oil palm areal extent from the Gunarso et al. (2013) remote sensing analysis is an underestimate of the true areal coverage of oil palm in maritime Southeast Asia.

The 1990-2010 change in oil palm cover dominates the land-cover-change-driven isoprene emissions changes in this region (Sect. 3.1); thus, the underestimate in oil palm areal cover likewise represents an underestimate in the globalmean ozone forcing from regional land cover change. Taking into account the smallholder estimates for Indonesia and Malaysia, the total regional expansion of oil palm cover for 1990-2010 increases to +16 Mha, which is considered to be an upper bound. Applying the land-area-based global-mean ozone forcing for regional oil palm expansion $\left(+1 \mathrm{~mW} \mathrm{~m}^{-2} \mathrm{Mha}^{-1}\right)$, based on the $\Delta \mathrm{LC}$ and $\Delta \mathrm{LC}-2005$ analyses, gives an estimate of $+16 \mathrm{~mW} \mathrm{~m}^{-2}$ for the globalmean ozone forcing from regional land cover change. This value is considered to be the upper bound of a best estimate of the global-mean ozone forcing from maritime Southeast Asian land cover change.

There is little variability in the magnitude of the forcing associated with the prescribed background atmosphere as application of the year 1990 background atmosphere $(\Delta \mathrm{LC}$ 1990atm) in lieu of the year 2010 background atmosphere $(\triangle \mathrm{LC})$ had little impact on the ozone and SOA forcings induced by land cover change (Table 5). The fact that local surface ozone reductions, rather than enhancements, are simulated in response to enhanced isoprene emissions (Fig. 1) suggests a $\mathrm{NO}_{x}$-sensitive chemical environment.

Taking into account the results of the sensitivity simulations, the best estimate of the global-mean forcing from ozone changes induced by regional 1990-2010 land cover change is $+9 \mathrm{~mW} \mathrm{~m}^{-2}$, with a range of +4 to $+16 \mathrm{~mW} \mathrm{~m}^{-2}$. The quantified range accounts only for uncertainties probed by the sensitivity studies.

\section{Conclusions and future work}

The best estimate of global-mean forcing from isoprene and monoterpene emission perturbations driven by regional land cover change - quantified here using simulations that apply satellite-derived land cover distributions and measured leaf-level isoprene and monoterpene BERs - indicates a positive forcing $\left(+8.4 \pm 0.7 \mathrm{~mW} \mathrm{~m}^{-2}\right)$, which is a warming impact. In absolute terms, the quantified forcing from 1990 to 2010 maritime Southeast Asian land cover change is small, particularly in comparison to the forcing associated with industrial-era perturbations of well-mixed greenhouse gases (e.g., Myhre et al., 2013). However, the ozone perturbations associated with changes in global anthropogenic emissions of non-methane VOCs over the industrial era (17502011) induced a global-mean stratospherically adjusted forcing on the order of $+30 \mathrm{~mW} \mathrm{~m}^{-2}$ (Myhre et al., 2013), which is only around 3 times the magnitude of the instantaneous ozone forcing associated with 1990-2010 land cover change in MSEA $\left(+9.2 \mathrm{~mW} \mathrm{~m}^{-2}\right)$. For comparison, the global ozone forcing driven by the 1990-2010 land cover change in MSEA is at the low end of the range of estimates for ozone forcing from global anthropogenic emission source sectors in year $2000\left(+5\right.$ to $\left.+80 \mathrm{~mW} \mathrm{~m}^{-2}\right)$ : for example, industry is $+15 \mathrm{~mW} \mathrm{~m}^{-2}$; household biofuel is $+28 \mathrm{~mW} \mathrm{~m}^{-2}$; road transport is $+50 \mathrm{~mW} \mathrm{~m}^{-2}$; power is $+53 \mathrm{~mW} \mathrm{~m}^{-2}$; and biomass burning is $+71 \mathrm{~mW} \mathrm{~m}^{-2}$ (Fuglestvedt et al., 2008; Unger et al., 2010). A multi-model study found that $20 \%$ reductions in NMVOCs (about 2$4 \mathrm{TgC}^{-1}$ ) in four large world regions (North America, East Asia, Europe, and South Asia) in 2001 led to global ozone forcings around $-1 \mathrm{~mW} \mathrm{~m}^{-2}$ (Fry et al., 2012).

The climate forcing quantified here represents the forcing induced by atmospheric composition changes driven by 1990-2010 land cover change in MSEA. Roughly $27 \%$ of the 2010 oil palm plantation areal cover in this region already existed in 1990 (Table 2). Applying the land-areabased global-mean ozone forcing for regional oil palm expansion that was calculated here $\left(+1 \mathrm{~mW} \mathrm{~m}^{-2} \mathrm{Mha}^{-1}\right)$, regional oil palm expansion over the modern era is responsible for a global-mean forcing of $+12.7 \mathrm{~mW} \mathrm{~m}^{-2}$ from induced ozone changes. Based on government-awarded leases, Carlson et al. (2012) project that at least 9.4 Mha of additional land in Indonesian Borneo alone will be converted to oil palm plantations over 2010-2020, indicating that additional climate forcing is expected from regional land cover change in coming years. For comparison, oil palm expansion over 1990-2010 for the entirety of MSEA was +9.6 Mha (Table 2).

The sensitivity analyses indicate that important factors driving uncertainty in the forcing include (1) uncertainty in the magnitude of the isoprene BER for oil palm and (2) uncertainty in the areal extent of oil palm expansion. The simulations find that the expansion of oil palm plantations is responsible for almost all of the land-cover-change-driven net increase in regional isoprene emissions (Sect. 3.1). Because the total magnitude of isoprene emissions from oil palm plantations scales linearly with the assigned leaf-level BER, the atmospheric composition changes and concomitant forcing from regional land cover change are strongly dependent on the magnitude of the assigned isoprene BER for oil palm plantations. An improved understanding of the isoprene BER for oil palm would strongly benefit the effort to quantify the environmental impacts of the recent large-scale changes in land cover in this sensitive region.

Our study has several limitations. The radiative forcing results are likely sensitive to the isoprene chemical mechanism, SOA production scheme, and convective transport and atmospheric transport schemes in the model. For example, this study applies the two-product scheme for SOA production (Tsigaridis and Kanakidou, 2007), but the appropriateness of using such schemes in global models is still under de- 
bate (e.g., Tsigaridis et al., 2014). Many recent global SOA model studies use fixed SOA yields for calculating SOA production from isoprene and monoterpene oxidation (e.g., Rap et al., 2018; Scott et al., 2017, 2018). For the $\Delta$ LC analysis, the global-mean SOA radiative forcing per unit of SOA burden change is $-115 \mathrm{~mW} \mathrm{~m}^{-2} \mathrm{Tg}^{-1}$. This value is largely consistent across the sensitivity analyses, ranging from -112 to $-119 \mathrm{~mW} \mathrm{~m}^{-2} \mathrm{Tg}^{-1}$. This metric can be used to estimate the SOA radiative forcing induced by the simulated isoprene and monoterpene emission changes under the assumption of fixed SOA yields. Assuming fixed SOA yields of $10 \%$ from the simulated monoterpene emission changes (e.g., Tsigaridis et al., 2014) and $1 \%$ from the simulated isoprene emission changes (lower end of range suggested by Kroll et al., 2005), in conjunction with the SOA forcing per burden metric, results in an SOA forcing of $-2.5 \mathrm{~mW} \mathrm{~m}^{-2}$ from 1990 to 2010 land cover change (i.e., $\triangle \mathrm{LC}$ analysis). The SOA radiative forcing based on fixed SOA yields is more than 3 times stronger than, but of the same sign as, the SOA radiative forcing calculated by the global model; in both cases, the SOA radiative forcing is negligible and partially offsets the positive forcing from ozone. For the $\Delta \mathrm{LC}$ analysis, the cumulative radiative forcing, considering impacts of both ozone and SOA changes, is $+8.4 \mathrm{~mW} \mathrm{~m}^{-2}$ computed by the model and $+6.7 \mathrm{~mW} \mathrm{~m}^{-2}$ computed using the simulated ozone forcing plus the SOA forcing computed here using fixed SOA yields. That is, using fixed SOA yields, the total radiative forcing would be slightly smaller in magnitude than, but the same sign as, the forcing simulated by the model. Several recent studies have applied slightly larger SOA yields: $+14.3 \%$ from monoterpenes and $+3.3 \%$ from isoprene (by mass; Rap et al., 2018; Scott et al., 2017, 2018 ). Using these larger SOA yields for the $\Delta \mathrm{LC}$ analysis results in an SOA forcing of $-19.4 \mathrm{~mW} \mathrm{~m}^{-2}$ and a total radiative forcing, taking into account the ozone forcing, of $-10.2 \mathrm{~mW} \mathrm{~m}^{-2}$, which is the opposite sign of that simulated by the model $\left(+8.4 \mathrm{~mW} \mathrm{~m}^{-2}\right)$. This analysis indicates that uncertainty associated with biogenic SOA yields from isoprene and monoterpene oxidation has a strong influence on the quantified forcing.

Seasonal variation in isoprene BERs has been observed for some tree species (e.g., Geron et al., 2000). Similarly, based on above-canopy isoprene flux measurements, observed meteorological variables, and the isoprene emission algorithms of the Model of Emissions of Gases and Aerosols from Nature (MEGAN; Guenther et al., 2006) model, Hewitt et al. (2011) suggest that isoprene emissions from oil palm plantations are under circadian control at the canopy scale; that is, the isoprene BER exhibits diurnal variability, peaking in the early afternoon. Keenan and Niinemets (2012) subsequently argued that the apparent circadian control calculated by Hewitt et al. (2011) is likely caused by inappropriate assignment of model parameters in the MEGAN model. One study reports apparent circadian control of oil palm isoprene emissions at the leaf level (Wilkinson et al., 2006). Like other global models, the YIBs model supports application of only a single invariant isoprene BER for each PFT or land cover type and, therefore, might misrepresent isoprene emission magnitudes if oil palm isoprene emissions are, in fact, under circadian control.

Previous work has shown that land cover change in MSEA impacts the environment in numerous ways, including by threatening plant and animal diversity (Sodhi et al., 2004), driving large GHG emissions (FAO, 2014; WRI, 2015), and damaging air quality through vegetation and peat burning (Gaveau et al., 2014; Koplitz et al., 2016). The simulations presented here indicate that isoprene and monoterpene emission perturbations provide an additional mechanism by which regional land cover change impacts the environment. While the impact on global radiative forcing is small, the ozone radiative forcing exceeds $+37 \mathrm{~mW} \mathrm{~m}^{-2}$ in some localities. This forcing mechanism can be expected to grow in importance in future years if oil palm expansion continues at a high rate.

Data availability. Numerical data used to make the figures or used to otherwise support the analysis are included as Supplement. Raw model output is available from the authors. All other data used as input to the model are listed in the references.

Supplement. The supplement related to this article is available online at: https://doi.org/10.5194/acp-18-16931-2018-supplement.

Author contributions. $\mathrm{KH}$ and NU designed the study. KH modified the model source code, performed the model simulations, and analyzed the model output. KH prepared the manuscript with revisions from NU.

Competing interests. The authors declare that they have no conflict of interest.

Acknowledgements. This project was supported in part by the facilities and staff of the Yale University Faculty of Arts and Sciences High Performance Computing Center. The authors thank Tim Killeen for providing the land cover classification data for maritime Southeast Asia and $\mathrm{Xu}$ Yue for model debugging support.

Edited by: Neil Harris

Reviewed by: three anonymous referees

\section{References}

Angiola, A., Mieville, A., and Granier, C.: MACCity (MACC/CityZEN EU projects) emissions dataset [Data files], Emissions of atmospheric Compounds \& Compilation 
of Ancillary Data, available at: http://eccad.sedoo.fr (last access: 13 July 2015), 2010.

Apel, E. C., Olson, J. R., Crawford, J. H., Hornbrook, R. S., Hills, A. J., Cantrell, C. A., Emmons, L. K., Knapp, D. J., Hall, S., Mauldin III, R. L., Weinheimer, A. J., Fried, A., Blake, D. R., Crounse, J. D., Clair, J. M. St., Wennberg, P. O., Diskin, G. S., Fuelberg, H. E., Wisthaler, A., Mikoviny, T., Brune, W., and Riemer, D. D.: Impact of the deep convection of isoprene and other reactive trace species on radicals and ozone in the upper troposphere, Atmos. Chem. Phys., 12, 1135-1150, https://doi.org/10.5194/acp-12-1135-2012, 2012.

Archibald, A. T., Jenkin, M. E., and Shallcross, D. E.: An isoprene mechanism intercomparison, Atmos. Environ., 44, 5356-5364, https://doi.org/10.1016/j.atmosenv.2009.09.016, 2010.

Arneth, A., Niinemets, Ü., Pressley, S., Bäck, J., Hari, P., Karl, T., Noe, S., Prentice, I. C., Serça, D., Hickler, T., Wolf, A., and Smith, B.: Process-based estimates of terrestrial ecosystem isoprene emissions: incorporating the effects of a direct CO2-isoprene interaction, Atmos. Chem. Phys., 7, 31-53, https://doi.org/10.5194/acp-7-31-2007, 2007.

Ashworth, K., Folberth, G., Hewitt, C. N., and Wild, O.: Impacts of near-future cultivation of biofuel feedstocks on atmospheric composition and local air quality, Atmos. Chem. Phys., 12, 919 939, https://doi.org/10.5194/acp-12-919-2012, 2012.

Atherton, C. A.: Organic nitrates in remote marine environments: Evidence for long-range transport, Geophys. Res. Lett., 16, 1289-1292, https://doi.org/10.1029/GL016i011p01289, 1989.

Atkinson, R. and Arey, J.: Gas-phase tropospheric chemistry of biogenic volatile organic compounds: A review, Atmos. Environ., 37, 197-219, https://doi.org/10.1016/S1352-2310(03)00391-1, 2003.

Baker, B., Bai, J.-H., Johnson, C., Cai, Z.-T., Li, Q.-J., Wang, Y.F., Guenther, A., Greenberg, J., Klinger, L., Geron, C., and Rasmussen, R.: Wet and dry season ecosystem level fluxes of isoprene and monoterpenes from a southeast Asian secondary forest and rubber tree plantation, Atmos. Environ., 39, 381-390, https://doi.org/10.1016/j.atmosenv.2004.07.033, 2005.

Ball, J. T., Woodrow, I. E., and Berry, J. A.: A model predicting stomatal conductance and its contribution to the control of photosynthesis under different environmental conditions, in: Progress in Photosynthesis Research (Vol. 4), edited by: Biggins, J., Martinus Nijhoff Publishers, Dordrecht, 221-224, 1987.

Bauer, S. E. and Koch, D.: Impact of heterogeneous sulfate formation at mineral dust surfaces on aerosol loads and radiative forcing in the Goddard Institute for Space Studies general circulation model, J. Geophys. Res., 110, D17202, https://doi.org/10.1029/2005JD005870, 2005.

Bauer, S. E., Koch, D., Unger, N., Metzger, S. M., Shindell, D. T., and Streets, D. G.: Nitrate aerosols today and in 2030: a global simulation including aerosols and tropospheric ozone, Atmos. Chem. Phys., 7, 5043-5059, https://doi.org/10.5194/acp-7-50432007, 2007a.

Bauer, S. E., Mishchenko, M. I., Lacis, A. A., Zhang, S., Perlwitz, J., and Metzger, S. M.: Do sulfate and nitrate coatings on mineral dust have important effects on radiative properties and climate modeling?, J. Geophys. Res., 112, D06307, https://doi.org/10.1029/2005JD006977, 2007b.

Beer, C., Reichstein, M., Tomelleri, E., Ciais, P., Jung, M., Carvalhais, N., Rödenbeck, C., Arain, M. A., Baldocchi, D., Bonan, G.
B., Bondeau, A., Cescatti, A., Lasslop, G., Lindroth, A., Lomas, M., Luyssaert, S., Margolis, H., Oleson, K. W., Roupsard, O., Veenendaal, E., Viovy, N., Williams, C., Woodward, F. I., and Papale, D.: Terrestrial gross carbon dioxide uptake: Global distribution and covariation with climate, Science, 329, 834-838, https://doi.org/10.1126/science.1184984, 2010.

Beirle, S., Huntrieser, H., and Wagner, T.: Direct satellite observation of lightning-produced $\mathrm{NO}_{x}$, Atmos. Chem. Phys., 10, 10965-10986, https://doi.org/10.5194/acp-10-10965-2010, 2010.

Bell, N., Koch, D., and Shindell, D. T.: Impacts of chemistryaerosol coupling on tropospheric ozone and sulfate simulations in a general circulation model, J. Geophys. Res., 110, D14305, https://doi.org/10.1029/2004JD005538, 2005.

Bian, H. and Prather, M. J.: Fast-J2: Accurate simulation of stratospheric photolysis in global chemical models, J. Atmos. Chem., 41, 281-296, https://doi.org/10.1023/A:1014980619462, 2002.

Bian, H., Prather, M. J., and Takemura, T.: Tropospheric aerosol impacts on trace gas budgets through photolysis, J. Geophys. Res., 108, 4242, https://doi.org/10.1029/2002JD002743, 2003.

Boersma, K. F., Eskes, H. J., Meijer, E. W., and Kelder, H. M.: Estimates of lightning $\mathrm{NO}_{x}$ production from GOME satellite observations, Atmos. Chem. Phys., 5, 2311-2331, https://doi.org/10.5194/acp-5-2311-2005, 2005.

Carlson, K. M., Curran, L. M., Asner, G. P., Pittman, A. M., Trigg, S. N., and Marion Adeney, J.: Carbon emissions from forest conversion by Kalimantan oil palm plantations, Nat. Clim. Change, 3, 283-287, https://doi.org/10.1038/nclimate1702, 2012.

Carlton, A. G., Wiedinmyer, C., and Kroll, J. H.: A review of Secondary Organic Aerosol (SOA) formation from isoprene, Atmos. Chem. Phys., 9, 4987-5005, https://doi.org/10.5194/acp-9-49872009, 2009.

Collatz, G. J., Ball, J. T., Grivet, C., and Berry, J. A.: Physiological and environmental regulation of stomatal conductance, photosynthesis and transpiration: A model that includes a laminar boundary layer, Agr. Forest Meteorol., 54, 107-136, https://doi.org/10.1016/0168-1923(91)90002-8, 1991.

Collins, W. J., Stevenson, D. S., Johnson, C. E., and Derwent, R. G.: Role of convection in determining the budget of odd hydrogen in the upper troposphere, J. Geophys. Res., 104, 26927-26941, https://doi.org/10.1029/1999JD900143, 1999.

Cronn, D. R. and Nutmagul, W.: Analysis of atmospheric hydrocarbons during winter MONEX, Tellus, 34, 159-165, https://doi.org/10.1111/j.2153-3490.1982.tb01803.x, 1982.

da Silva, G., Graham, C., and Wang, Z.-F.: Unimolecular $\beta$ hydroxyperoxy radical decomposition with $\mathrm{OH}$ recycling in the photochemical oxidation of isoprene, Environ. Sci. Technol., 44, 250-256, https://doi.org/10.1021/es900924d, 2010.

DeFries, R. S., Hansen, M. C., Townshend, J. R. G., Janetos, A. C., and Loveland, T. R.: A new global 1-km dataset of percentage tree cover derived from remote sensing, Global Change Biol., 6, 247-254, https://doi.org/10.1046/j.1365-2486.2000.00296.x, 2000.

Dietz, J., Hölscher, D., Leuschner, C., Malik, A., and Amir, M. A.: Forest structure as influenced by different types of community forestry in a lower montane rainforest of Central Sulawesi, Indonesia, in: Stability of Tropical Rainforest Margins: Linking Ecological, Economic and Social Constraints of Land Use and Conservation, edited by: Tscharntke, T., Leuschner, C., Zeller, 
M., Guhardja, E., and Biden, A., Springer-Verlag, Berlin, 131146, 2007.

Draper, D. C., Farmer, D. K., Desyaterik, Y., and Fry, J. L.: A qualitative comparison of secondary organic aerosol yields and composition from ozonolysis of monoterpenes at varying concentrations of $\mathrm{NO}_{2}$, Atmos. Chem. Phys., 15, 12267-12281, https://doi.org/10.5194/acp-15-12267-2015, 2015.

Emmerson, K. M. and Evans, M. J.: Comparison of tropospheric gas-phase chemistry schemes for use within global models, Atmos. Chem. Phys., 9, 1831-1845, https://doi.org/10.5194/acp-91831-2009, 2009.

Fan, Y., Roupsard, O., Bernoux, M., Le Maire, G., Panferov, O., Kotowska, M. M., and Knohl, A.: A sub-canopy structure for simulating oil palm in the Community Land Model (CLM-Palm): phenology, allocation and yield, Geosci. Model Dev., 8, 37853800, https://doi.org/10.5194/gmd-8-3785-2015, 2015.

FAO: FAOSTAT Emissions Database, Food and Agriculture Organization of the United Nations, http://www.fao.org/faostat/en/\#data (last access: 25 September 2017), 2014.

Farquhar, G. D. and von Caemmerer, S.: Modelling of photosynthetic response to environmental conditions, in: Physiological Plant Ecology II, edited by: Lange, O. L., Nobel, P. S., Osmond, C. B., and Ziegler, H., Springer-Verlag, Berlin, 549-587, 1982.

Farquhar, G. D., von Caemmerer, S., and Berry, J. A.: A biochemical model of photosynthetic $\mathrm{CO}_{2}$ assimilation in leaves of C3 species, Planta, 149, 78-90, https://doi.org/10.1007/BF00386231, 1980.

Folkins, I., Chatfield, R., Baumgardner, D., and Proffitt, M.: Biomass burning and deep convection in southeastern Asia: Results from ASHOE/MAESA, J. Geophys. Res., 102, 1329113299, https://doi.org/10.1029/96JD03711, 1997.

Fowler, D., Nemitz, E., Misztal, P., Di Marco, C., Skiba, U., Ryder, J., Helfter, C., Cape, J. N., Owen, S., Dorsey, J., Gallagher, M. W., Coyle, M., Phillips, G., Davison, B., Langford, B., MacKenzie, R., Muller, J., Siong, J., Dari-Salisburgo, C., Di Carlo, P., Aruffo, E., Giammaria, F., Pyle, J. A., and Hewitt, C. N.: Effects of land use on surface-atmosphere exchanges of trace gases and energy in Borneo: Comparing fluxes over oil palm plantations and a rainforest, Philos. T. R. Soc. B, 366, 3196-3209, https://doi.org/10.1098/rstb.2011.0055, 2011.

Friedman, B. and Farmer, D. K.: SOA and gas phase organic acid yields from the sequential photooxidation of seven monoterpenes, Atmos. Environ., 187, 335-345, https://doi.org/10.1016/j.atmosenv.2018.06.003, 2018.

Fry, M. M., Naik, V., West, J. J., Schwarzkopf, M. D., Fiore, A. M., Collins, W. J., Dentener, F. J., Shindell, D. T., Atherton, C., Bergmann, D., Duncan, B. N., Hess, P., MacKenzie, I. A., Marmer, E., Schultz, M. G., Szopa, S., Wild, O., and Zeng, G.: The influence of ozone precursor emissions from four world regions on tropospheric composition and radiative climate forcing, J. Geophys. Res., 117, D07306, https://doi.org/10.1029/2011JD017134, 2012.

Fuglestvedt, J., Berntsen, T., Myhre, G., Rypdal, K., and Skeie, R. B.: Climate forcing from the transport sectors, P. Natl. Acad. Sci. USA, 105, 454-458, https://doi.org/10.1073/pnas.0702958104, 2008

Gaveau, D. L. A., Salim, M. A., Hergoualc'h, K., Locatelli, B., Sloan, S., Wooster, M., Marlier, M. E., Molidena, E., Yaen, H., DeFries, R., Verchot, L., Murdiyarso, D., Nasi, R., Holm- gren, P., and Sheil, D.: Major atmospheric emissions from peat fires in Southeast Asia during non-drought years: Evidence from the 2013 Sumatran fires, Sci. Rep., 4, 6112, https://doi.org/10.1038/srep06112, 2014.

Geron, C., Guenther, A., Sharkey, T., and Arnts, R. R.: Temporal variability in basal isoprene emission factor, Tree Physiol., 20, 799-805, 2000.

Geron, C., Owen, S., Guenther, A., Greenberg, J., Rasmussen, R., Bai, J. H., Li, Q.-J., and Baker, B.: Volatile organic compounds from vegetation in southern Yunnan Province, China: Emission rates and some potential regional implications, Atmos. Environ., 40, 1759-1773, https://doi.org/10.1016/j.atmosenv.2005.11.022, 2006.

Gery, M. W., Whitten, G. Z., Killus, J. P., and Dodge, M. C.: A photochemical kinetics mechanism for urban and regional scale computer modeling, J. Geophys. Res.-Atmos., 94, 12925-12956, https://doi.org/10.1029/JD094iD10p12925, 1989.

Granier, C., Bessagnet, B., Bond, T., D’Angiola, A., Denier van der Gon, H., Frost, G. J., Heil, A., Kaiser, J. W., Kinne, S., Klimont, Z., Kloster, S., Lamarque, J.-F., Liousse, C., Masui, T., Meleux, F., Mieville, A., Ohara, T., Raut, J.-C., Riahi, K., Schultz, M. G., Smith, S. J., Thompson, A., van Aardenne, J., van der Werf, G. R., and van Vuuren, D. P.: Evolution of anthropogenic and biomass burning emissions of air pollutants at global and regional scales during the 1980-2010 period, Climatic Change, 109, 163-190, https://doi.org/10.1007/s10584011-0154-1, 2011.

Guenther, A., Hewitt, C. N., Erickson, D., Fall, R., Geron, C., Graedel, T., Harley, P., Klinger, L., Lerdau, M., McKay, W. A., Pierce, T., Scholes, B., Steinbrecher, R., Tallamraju, R., Taylor, J., and Zimmerman, P.: A global model of natural volatile organic compound emissions, J. Geophys. Res.-Atmos., 100, 8873-8892, https://doi.org/10.1029/94JD02950, 1995.

Guenther, A., Karl, T., Harley, P., Wiedinmyer, C., Palmer, P. I., and Geron, C.: Estimates of global terrestrial isoprene emissions using MEGAN (Model of Emissions of Gases and Aerosols from Nature), Atmos. Chem. Phys., 6, 3181-3210, https://doi.org/10.5194/acp-6-3181-2006, 2006.

Guenther, A. B., Jiang, X., Heald, C. L., Sakulyanontvittaya, T., Duhl, T., Emmons, L. K., and Wang, X.: The Model of Emissions of Gases and Aerosols from Nature version 2.1 (MEGAN2.1): an extended and updated framework for modeling biogenic emissions, Geosci. Model Dev., 5, 1471-1492, https://doi.org/10.5194/gmd-5-1471-2012, 2012.

Gunarso, P., Hartoyo, M. E., Agus, F., and Killeen, T. J.: Oil palm and land use change in Indonesia, Malaysia, and Papua New Guinea: Reports from the Technical Panels of the 2nd Greenhouse Gas Working Group of the Roundtable on Sustainable Palm Oil (RSPO), Roundtable on Sustainable Palm Oil, Kuala Lumpur, Malaysia, 2013.

Hallquist, M., Stewart, D. J., Stephenson, S. K., and Cox, R. A.: Hydrolysis of $\mathrm{N}_{2} \mathrm{O}_{5}$ on sub-micron sulfate aerosols, Phys. Chem. Chem. Phys., 5, 3453-3463, https://doi.org/10.1039/b301827j, 2003.

Hansen, M. C., DeFries, R. S., Townshend, J. R. G., Carroll, M., Dimiceli, C., and Sohlberg, R. A.: Global percent tree cover at a spatial resolution of 500 meters: First results of the MODIS vegetation continuous fields algo- 
rithm, Earth Interact., 7, 1-15, https://doi.org/10.1175/10873562(2003)007<0001:GPTCAA>2.0.CO;2, 2003.

Hanson, D. and Mauersberger, K.: Laboratory studies of the nitric acid trihydrate: Implications for the south polar stratosphere, Geophys. Res. Lett., 15, 855-858, https://doi.org/10.1029/GL015i008p00855, 1988.

Hantson, S., Knorr, W., Schurgers, G., Pugh, T. A. M., and Arneth, A.: Global isoprene and monoterpene emissions under changing climate, vegetation, $\mathrm{CO}_{2}$ and land use, Atmos. Environ., 155, 3545, https://doi.org/10.1016/j.atmosenv.2017.02.010, 2017.

Harper, K. L., Zheng, Y., and Unger, N.: Advances in representing interactive methane in ModelE2-YIBs (version 1.1), Geosci. Model Dev., 11, 4417-4434, https://doi.org/10.5194/gmd-114417-2018, 2018.

Heil, A. and Schultz, M. G.: Interpolated ACCMIP and RCP emission dataset [Data files], Research Center Jülich, Jülich, Germany, 2014.

Hewitt, C. N., MacKenzie, A. R., Di Carlo, P., Di Marco, C. F., Dorsey, J. R., Evans, M., Fowler, D., Gallagher, M. W., Hopkins, J. R., Jones, C. E., Langford, B., Lee, J. D., Lewis, A. C., Lim, S. F., McQuaid, J., Misztal, P., Moller, S. J., Monks, P. S., Nemitz, E., Oram, D. E., Owen, S. M., Phillips, G. J., Pugh, T. A. M., Pyle, J. A., Reeves, C. E., Ryder, J., Siong, J., Skiba, U., and Stewart, D. J.: Nitrogen management is essential to prevent tropical oil palm plantations from causing groundlevel ozone pollution, P. Natl. Acad. Sci. USA, 106, 1844718451, https://doi.org/10.1073/pnas.0907541106, 2009.

Hewitt, C. N., Lee, J. D., MacKenzie, A. R., Barkley, M. P., Carslaw, N., Carver, G. D., Chappell, N. A., Coe, H., Collier, C., Commane, R., Davies, F., Davison, B., DiCarlo, P., Di Marco, C. F., Dorsey, J. R., Edwards, P. M., Evans, M. J., Fowler, D., Furneaux, K. L., Gallagher, M., Guenther, A., Heard, D. E., Helfter, C., Hopkins, J., Ingham, T., Irwin, M., Jones, C., Karunaharan, A., Langford, B., Lewis, A. C., Lim, S. F., MacDonald, S. M., Mahajan, A. S., Malpass, S., McFiggans, G., Mills, G., Misztal, P., Moller, S., Monks, P. S., Nemitz, E., Nicolas-Perea, V., Oetjen, H., Oram, D. E., Palmer, P. I., Phillips, G. J., Pike, R., Plane, J. M. C., Pugh, T., Pyle, J. A., Reeves, C. E., Robinson, N. H., Stewart, D., Stone, D., Whalley, L. K., and Yin, X.: Overview: oxidant and particle photochemical processes above a south-east Asian tropical rainforest (the OP3 project): introduction, rationale, location characteristics and tools, Atmos. Chem. Phys., 10, 169-199, https://doi.org/10.5194/acp-10-169-2010, 2010.

Hewitt, C. N., Ashworth, K., Boynard, A., Guenther, A., Langford, B., MacKenzie, A. R., Misztal, P. K., Nemitz, E., Owen, S. M., Possell, M., Pugh, T. A. M., Ryan, A. C., and Wild, O.: Ground-level ozone influenced by circadian control of isoprene emissions, Nat. Geosci., 4, 671-674, https://doi.org/10.1038/ngeo1271, 2011.

Hollaway, M. J., Arnold, S. R., Collins, W. J., Folberth, G., and Rap, A.: Sensitivity of midnineteenth century tropospheric ozone to atmospheric chemistry-vegetation interactions, J. Geophys. Res.-Atmos., 122, 2452-2473, https://doi.org/10.1002/2016JD025462, 2017.

Hooijer, A., Page, S., Canadell, J. G., Silvius, M., Kwadijk, J., Wösten, H., and Jauhiainen, J.: Current and future $\mathrm{CO}_{2}$ emissions from drained peatlands in Southeast Asia, Biogeosciences, 7, 1505-1514, https://doi.org/10.5194/bg-7-1505-2010, 2010.
Houweling, S., Dentener, F., and Lelieveld, J.: The impact of nonmethane hydrocarbon compounds on tropospheric photochemistry, J. Geophys. Res., 103, 10673-10696, https://doi.org/10.1029/97JD03582, 1998.

Indonesian Ministry of Agriculture: Tree Crop Estate Statistics of Indonesia 2015-2017, Directorate General of Estate Crops, Ministry of Agriculture, Indonesia, 2017.

Indrarto, G. B., Murharjanti, P., Khatarina, J., Pulungan, I., Ivalerina, F., Rahman, J., Prana, M. N., Resosudarmo, I. A. P., and Muharrom, E.: The context of REDD+ in Indonesia: Drivers, agents and institutions (Working Paper 92), CIFOR, Bogor, Indonesia, 2012.

Jardine, A. B., Jardine, K. J., Fuentes, J. D., Martin, S. T., Martins, G., Durgante, F., Carneiro, V., Higuchi, N., Manzi, A. O., and Chambers, J. Q.: Highly reactive light-dependent monoterpenes in the Amazon, Geophys. Res. Lett., 42, 1576-1583, https://doi.org/10.1002/2014GL062573, 2015.

Jardine, K. J., Jardine, A. B., Holm, J. A., Lombardozzi, D. L., Negron-Juarez, R. I., Martin, S. T., Beller, H. R., Gimenez, B. O., Higuchi, N., and Chambers, J. Q.: Monoterpene 'thermometer' of tropical forest-atmosphere response to climate warming, Plant Cell Environ., 40, 441-452, https://doi.org/10.1111/pce.12879, 2017.

Jokinen, T., Berndt, T., Makkonen, R., Kerminen, V.-M., Junninen, H., Paasonen, P., Stratmann, F., Herrmann, H., Guenther, A. B., Worsnop, D. R., Kulmala, M., Ehn, M., and Sipilä, M.: Production of extremely low volatile organic compounds from biogenic emissions: Measured yields and atmospheric implications, P. Natl. Acad. Sci. USA, 112, 7123-7128, https://doi.org/10.1073/pnas.1423977112, 2015.

Kane, S. M., Caloz, F., and Leu, M.-T.: Heterogeneous uptake of gaseous $\mathrm{N}_{2} \mathrm{O}_{5}$ by $\left(\mathrm{NH}_{4}\right)_{2} \mathrm{SO}_{4}, \mathrm{NH}_{4} \mathrm{HSO}_{4}$, and $\mathrm{H}_{2} \mathrm{SO}_{4}$ aerosols, J. Phys. Chem. A, 105, 6465-6470, https://doi.org/10.1021/jp010490x, 2001.

Keenan, T. F. and Niinemets, Ü.: Circadian control of global isoprene emissions, Nat. Geosci., 5, 435, https://doi.org/10.1038/ngeo1500, 2012.

Kesselmeier, J. and Staudt, M.: Biogenic volatile organic compounds (VOC): An overview on emission, physiology and ecology, J. Atmos. Chem., 33, 23-88, https://doi.org/10.1023/A:1006127516791, 1999.

Klinger, L. F., Li, Q.-J., Guenther, A. B., Greenberg, J. P., Baker, B., and Bai, J.-H.: Assessment of volatile organic compound emissions from ecosystems of China, J. Geophys. Res.-Atmos., 107, 4603, https://doi.org/10.1029/2001JD001076, 2002.

Knote, C., Tuccella, P., Curci, G., Emmons, L., Orlando, J. J., Madronich, S., Baró, R., Jiménez-Guerrero, P., Luecken, D., Hogrefe, C., Forkel, R., Werhahn, J., Hirtl, M., Perez, J. L., San José, R., Giordano, L., Brunner, D., Yahya, K., and Zhang, Y.: Influence of the choice of gas-phase mechanism on predictions of key gaseous pollutants during the AQMEII phase-2 intercomparison, Atmos. Environ., 115, 553568, https://doi.org/10.1016/j.atmosenv.2014.11.066, 2015.

Koch, D., Schmidt, G. A., and Field, C. V.: Sulfur, sea salt, and radionuclide aerosols in GISS ModelE, J. Geophys. Res., 111, D06206, https://doi.org/10.1029/2004JD005550, 2006.

Koplitz, S. N., Mickley, L. J., Marlier, M. E., Buonocore, J. J., Kim, P. S., Liu, T., Sulprizio, M. P., DeFries, R. S., Jacob, D. J., Schwartz, J., Pongsiri, M., and Myers, S. S.: Public health 
impacts of the severe haze in Equatorial Asia in SeptemberOctober 2015: Demonstration of a new framework for informing fire management strategies to reduce downwind smoke exposure, Environ. Res. Lett., 11, 094023, https://doi.org/10.1088/17489326/11/9/094023, 2016.

Kositsup, B., Montpied, P., Kasemsap, P., Thaler, P., Améglio, T., and Dreyer, E.: Photosynthetic capacity and temperature responses of photosynthesis of rubber trees (Hevea brasiliensis Müll. Arg.) acclimate to changes in ambient temperatures, Trees, 23, 357-365, https://doi.org/10.1007/s00468-008-0284-x, 2009.

Kotchenruther, R. A., Jaffe, D. A., and Jaeglé, L.: Ozone photochemistry and the role of peroxyacetyl nitrate in the springtime northeastern Pacific troposphere: Results from the Photochemical Ozone Budget of the Eastern North Pacific Atmosphere (PHOBEA) campaign, J. Geophys. Res., 106, 2873128742, https://doi.org/10.1029/2000JD000060, 2001.

Krisnawati, H., Varis, E., Kallio, M., and Kanninen, M.: Paraserianthes falcataria (L.) Nielsen: Ecology, silviculture and productivity, Center for International Forestry Research, Bogor, Indonesia, 2011.

Kroll, J. H., Ng, N. L., Murphy, S. M., Flagan, R. C., and Seinfeld, J. H.: Secondary organic aerosol formation from isoprene photooxidation under high- $\mathrm{NO}_{x}$ conditions, Geophys. Res. Lett., 32, L18808, https://doi.org/10.1029/2005GL023637, 2005.

Lacis, A. A., Wuebbles, D. J., and Logan, J. A.: Radiative forcing of climate by changes in the vertical distribution of ozone, J. Geophys. Res., 95, 9971-9981, https://doi.org/10.1029/JD095iD07p09971, 1990.

Lamarque, J.-F., Bond, T. C., Eyring, V., Granier, C., Heil, A., Klimont, Z., Lee, D., Liousse, C., Mieville, A., Owen, B., Schultz, M. G., Shindell, D., Smith, S. J., Stehfest, E., Van Aardenne, J., Cooper, O. R., Kainuma, M., Mahowald, N., McConnell, J. R., Naik, V., Riahi, K., and van Vuuren, D. P.: Historical (1850-2000) gridded anthropogenic and biomass burning emissions of reactive gases and aerosols: methodology and application, Atmos. Chem. Phys., 10, 7017-7039, https://doi.org/10.5194/acp-10-7017-2010, 2010.

Langford, B., Misztal, P. K., Nemitz, E., Davison, B., Helfter, C., Pugh, T. A. M., MacKenzie, A. R., Lim, S. F., and Hewitt, C. N.: Fluxes and concentrations of volatile organic compounds from a South-East Asian tropical rainforest, Atmos. Chem. Phys., 10, 8391-8412, https://doi.org/10.5194/acp-10-8391-2010, 2010.

Lathière, J., Hauglustaine, D. A., Friend, A. D., De NobletDucoudré, N., Viovy, N., and Folberth, G. A.: Impact of climate variability and land use changes on global biogenic volatile organic compound emissions, Atmos. Chem. Phys., 6, 2129-2146, https://doi.org/10.5194/acp-6-2129-2006, 2006.

Lee, J. S. H., Abood, S., Ghazoul, J., Barus, B., Obidzinski, K., and Koh, L. P.: Environmental impacts of large-scale oil palm enterprises exceed that of smallholdings in Indonesia, Conserv. Lett., 7, 25-33, https://doi.org/10.1111/conl.12039, 2014.

Legros, S., Mialet-Serra, I., Caliman, J.-P., Siregar, F. A., ClémentVidal, A., and Dingkuhn, M.: Phenology and growth adjustments of oil palm (Elaeis guineensis) to photoperiod and climate variability, Ann. Bot.-London, 104, 1171-1182, https://doi.org/10.1093/aob/mcp214, 2009.

Lelieveld, J., Butler, T. M., Crowley, J. N., Dillon, T. J., Fischer, H., Ganzeveld, L., Harder, H., Lawrence, M. G., Martinez, M., Taraborrelli, D., and Williams, J.: Atmospheric oxidation capacity sustained by a tropical forest, Nature, 452, 737-740, https://doi.org/10.1038/nature06870, 2008.

Li, Y., Lan, G., and Xia, Y.: Rubber trees demonstrate a clear retranslocation under seasonal drought and cold stresses, Front. Plant Sci., 07, 1-11, https://doi.org/10.3389/fpls.2016.01907, 2016.

Llusia, J., Sardans, J., Niinemets, Ü., Owen, S. M., and Peñuelas, J.: A screening study of leaf terpene emissions of 43 rainforest species in Danum Valley Conservation Area (Borneo) and their relationships with chemical and morphological leaf traits, Plant Biosyst., 148, 307-317, https://doi.org/10.1080/11263504.2013.770803, 2014.

Lockwood, A. L., Shepson, P. B., Fiddler, M. N., and Alaghmand, M.: Isoprene nitrates: preparation, separation, identification, yields, and atmospheric chemistry, Atmos. Chem. Phys., 10, 6169-6178, https://doi.org/10.5194/acp-10-6169-2010, 2010.

Mao, J., Ren, X., Zhang, L., Van Duin, D. M., Cohen, R. C., Park, J.-H., Goldstein, A. H., Paulot, F., Beaver, M. R., Crounse, J. D., Wennberg, P. O., DiGangi, J. P., Henry, S. B., Keutsch, F. N., Park, C., Schade, G. W., Wolfe, G. M., Thornton, J. A., and Brune, W. H.: Insights into hydroxyl measurements and atmospheric oxidation in a California forest, Atmos. Chem. Phys., 12, 8009-8020, https://doi.org/10.5194/acp-12-8009-2012, 2012.

Margono, B. A., Potapov, P. V., Turubanova, S., Stolle, F., and Hansen, M. C.: Primary forest cover loss in Indonesia over 2000-2012, Nat. Clim. Change, 4, 730-735, https://doi.org/10.1038/nclimate2277, 2014.

Martinez, M., Harder, H., Kubistin, D., Rudolf, M., Bozem, H., Eerdekens, G., Fischer, H., Klüpfel, T., Gurk, C., Königstedt, R., Parchatka, U., Schiller, C. L., Stickler, A., Williams, J., and Lelieveld, J.: Hydroxyl radicals in the tropical troposphere over the Suriname rainforest: airborne measurements, Atmos. Chem. Phys., 10, 3759-3773, https://doi.org/10.5194/acp10-3759-2010, 2010.

McPeters, R., Kroon, M., Labow, G., Brinksma, E., Balis, D., Petropavlovskikh, I., Veefkind, J., Bhartia, P., and Levelt, P.: Validation of the aura ozone monitoring instrument total column ozone product, J. Geophys. Res.-Atmos., 113, D15S14, https://doi.org/10.1029/2007JD008802, 2008.

Meijide, A., Röll, A., Fan, Y., Herbst, M., Niu, F., Tiedemann, F., June, T., Rauf, A., Hölscher, D., and Knohl, A.: Controls of water and energy fluxes in oil palm plantations: Environmental variables and oil palm age, Agr. Forest Meteorol., 239, 71-85, https://doi.org/10.1016/j.agrformet.2017.02.034, 2017.

Meinshausen, M., Smith, S. J., Calvin, K., Daniel, J. S., Kainuma, M. L. T., Lamarque, J.-F., Matsumoto, K., Montzka, S. A., Raper, S. C. B., Riahi, K., Thomson, A., Velders, G. J. M., and van Vuuren, D. P. P.: The RCP greenhouse gas concentrations and their extensions from 1765 to 2300 , Clim. Change, 109, 213241, https://doi.org/10.1007/s10584-011-0156-z, 2011.

Miettinen, J., Hooijer, A., Vernimmen, R., Liew, S. C., and Page, S. E.: From carbon sink to carbon source: Extensive peat oxidation in insular Southeast Asia since 1990, Environ. Res. Lett., 12, 024014, https://doi.org/10.1088/1748-9326/aa5b6f, 2017.

Miller, R. L., Cakmur, R. V., Perlwitz, J., Geogdzhayev, I. V., Ginoux, P., Koch, D., Kohfeld, K. E., Prigent, C., Ruedy, R., Schmidt, G. A., and Tegen, I.: Mineral dust aerosols in the NASA Goddard Institute for Space Sciences ModelE at- 
mospheric general circulation model, J. Geophys. Res., 111, D06208, https://doi.org/10.1029/2005JD005796, 2006.

Misztal, P. K., Nemitz, E., Langford, B., Di Marco, C. F., Phillips, G. J., Hewitt, C. N., MacKenzie, A. R., Owen, S. M., Fowler, D., Heal, M. R., and Cape, J. N.: Direct ecosystem fluxes of volatile organic compounds from oil palms in South-East Asia, Atmos. Chem. Phys., 11, 8995-9017, https://doi.org/10.5194/acp11-8995-2011, 2011.

Miyoshi, A., Hatakeyama, S., and Washida, N.: OH radicalinitiated photooxidation of isoprene: An estimate of global CO production, J. Geophys. Res., 99, 18779-18787, https://doi.org/10.1029/94JD01334, 1994.

Moxim, W. J., Levy II, H., and Kasibhatla, P. S.: Simulated global tropospheric PAN: Its transport and impact on $\mathrm{NO}_{x}, \mathrm{~J}$. Geophys. Res., 101, 12621-12638, https://doi.org/10.1029/96JD00338, 1996.

Myhre, G., Shindell, D., Bréon, F.-M., Collins, W., Fuglestvedt, J., Huang, J., Koch, D., Lamarque, J.-F., Lee, D., Mendoza, B., Nakajima, T., Robock, A., Stephens, G., Takemura, T., and Zhang, H.: Anthropogenic and natural radiative forcing, in: Climate Change 2013: The Physical Science Basis. Contribution of Working Group I to the Fifth Assessment Report of the Intergovernmental Panel on Climate Change, edited by: Stocker, T. F., Qin, D., Plattner, G.-K., Tignor, M., Allen, S. K., Boschung, J., Nauels, A., Xia, Y., Bex, V., and Midgley, P. M., Cambridge University Press, Cambridge, United Kingdom and New York, 2013.

Oleson, K. W., Lawrence, D. M., Bonan, G. B., Flanner, M. G., Kluzek, E., Lawrence, P. J., Levis, S., Swenson, S. C., and Thornton, P. E.: Technical description of version 4.0 of the Community Land Model (CLM), Technical Note No. NCAR/TN-478+STR, National Center for Atmospheric Research, Boulder, Colorado, 2010.

Page, S. E., Siegert, F., Rieley, J. O., Boehm, H.-D. V., Jaya, A., and Limin, S.: The amount of carbon released from peat and forest fires in Indonesia during 1997, Nature, 420, 61-65, https://doi.org/10.1038/nature01131, 2002.

Paulot, F., Crounse, J. D., Kjaergaard, H. G., Kürten, A., St. Clair, J. M., Seinfeld, J. H., and Wennberg, P. O.: Unexpected epoxide formation in the gas-phase photooxidation of isoprene, Science, 325, 730-733, https://doi.org/10.1126/science.1172910, 2009.

Peeters, J., Nguyen, T. L., and Vereecken, L.: $\mathrm{HO}_{x}$ radical regeneration in the oxidation of isoprene, Phys. Chem. Chem. Phys., 11, 5935-5939, https://doi.org/10.1039/B908511D, 2009.

Price, C. and Rind, D.: A simple lightning parameterization for calculating global lightning distributions, J. Geophys. Res., 97, 9919-9933, https://doi.org/10.1029/92JD00719, 1992.

Price, C., Penner, J., and Prather, M.: $\mathrm{NO}_{x}$ from lightning 1. Global distribution based on lightning physics, J. Geophys. Res., 102, 5929-5941, https://doi.org/10.1029/96JD03504, 1997.

Rakkibu, M. G.: Photosynthesis in a tropical montane rainforest of Southeast Asia: Field measurements and model analysis, Doctoral dissertation, Georg-August-Universität Göttingen, Göttingen, Germany, 2008.

Rap, A., Scott, C. E., Reddington, C. L., Mercado, L., Ellis, R. J., Garraway, S., Evans, M. J., Beerling, D. J., MacKenzie, A. R., Hewitt, C. N., and Spracklen, D. V.: Enhanced global primary production by biogenic aerosol via diffuse radiation fertilization,
Nat. Geosci., 11, 640-644, https://doi.org/10.1038/s41561-0180208-3, 2018.

Rayner, N. A., Parker, D. E., Horton, E. B., Folland, C. K., Alexander, L. V., and Rowell, D. P.: Global analyses of sea surface temperature, sea ice, and night marine air temperature since the late nineteenth century, J. Geophys. Res., 108, 4407, https://doi.org/10.1029/2002JD002670, 2003.

Riahi, K., Grübler, A., and Nakicenovic, N.: Scenarios of longterm socio-economic and environmental development under climate stabilization, Technol. Forecast. Soc., 74, 887-935, https://doi.org/10.1016/j.techfore.2006.05.026, 2007.

Ritchie, R. J. and Runcie, J. W.: A portable reflectanceabsorptance-transmittance meter for photosynthetic work on vascular plant leaves, Photosynthetica, 52, 614-626, https://doi.org/10.1007/s11099-014-0069-y, 2014.

Scales, B. R. and Marsden, S. J.: Biodiversity in small-scale tropical agroforests: A review of species richness and abundance shifts and the factors influencing them, Environ. Conserv., 35, 160 172, https://doi.org/10.1017/S0376892908004840, 2008.

Schmidt, G. A., Kelley, M., Nazarenko, L., Ruedy, R., Russell, G. L., Aleinov, I., Bauer, M., Bauer, S. E., Bhat, M. K., Bleck, R., Canuto, V., Chen, Y.-H., Cheng, Y., Clune, T. L., Del Genio, A., de Fainchtein, R., Faluvegi, G., Hansen, J. E., Healy, R. J., Kiang, N. Y., Koch, D., Lacis, A. A., LeGrande, A. N., Lerner, J., Lo, K. K., Matthews, E. E., Menon, S., Miller, R. L., Oinas, V., Oloso, A. O., Perlwitz, J. P., Puma, M. J., Putman, W. M., Rind, D., Romanou, A., Sato, M., Shindell, D. T., Sun, S., Syed, R. A., Tausnev, N., Tsigaridis, K., Unger, N., Voulgarakis, A., Yao, M.-S., and Zhang, J.: Configuration and assessment of the GISS ModelE2 contributions to the CMIP5 archive, J. Adv. Model. Earth Sy., 6, 141-184, https://doi.org/10.1002/2013MS000265, 2014.

Schultz, M. G., Heil, A., Hoelzemann, J. J., Spessa, A., Thonicke, K., Goldammer, J. G., Held, A. C., Pereira, J. M. C., and van het Bolscher, M.: Global wildland fire emissions from 1960 to 2000, Global Biogeochem. Cy., 22, GB2002, https://doi.org/10.1029/2007GB003031, 2008.

Scott, C. E., Monks, S. A., Spracklen, D. V., Arnold, S. R., Forster, P. M., Rap, A., Carslaw, K.S., Chipperfield, M. P., Reddington, C. L. S., and Wilson, C.: Impact on short-lived climate forcers (SLCFs) from a realistic land-use change scenario via changes in biogenic emissions, Faraday Discuss., 200, 101-120, https://doi.org/10.1039/c7fd00028f, 2017.

Scott, C. E., Monks, S. A., Spracklen, D. V., Arnold, S. R., Forster, P. M., Rap, A., Äijälä, M., Artaxo, P., Carslaw, K. S., Chipperfield, M. P., Ehn, M., Gilardoni, S., Heikkinen, L., Kulmala, M., Petäjä, T., Reddington, C. L. S., Rizzo, L. V., Swietlicki, E., Vignati, E., and Wilson, C.: Impact on short-lived climate forcers increases projected warming due to deforestation, Nat. Commun., 9, 1-9, https://doi.org/10.1038/s41467-017-02412-4, 2018.

Shindell, D. T., Faluvegi, G., and Bell, N.: Preindustrial-to-presentday radiative forcing by tropospheric ozone from improved simulations with the GISS chemistry-climate GCM, Atmos. Chem. Phys., 3, 1675-1702, https://doi.org/10.5194/acp-3-1675-2003, 2003.

Shindell, D. T., Faluvegi, G., Unger, N., Aguilar, E., Schmidt, G. A., Koch, D. M., Bauer, S. E., and Miller, R. L.: Simulations of preindustrial, present-day, and 2100 conditions in the NASA GISS composition and climate model G-PUCCINI, At- 
mos. Chem. Phys., 6, 4427-4459, https://doi.org/10.5194/acp-64427-2006, 2006.

Shindell, D. T., Pechony, O., Voulgarakis, A., Faluvegi, G., Nazarenko, L., Lamarque, J.-F., Bowman, K., Milly, G., Kovari, B., Ruedy, R., and Schmidt, G. A.: Interactive ozone and methane chemistry in GISS-E2 historical and future climate simulations, Atmos. Chem. Phys., 13, 2653-2689, https://doi.org/10.5194/acp-13-2653-2013, 2013.

Sillman, S.: The relation between ozone, NOx and hydrocarbons in urban and polluted rural environments, Atmos. Environ., 33, 1821-1845, https://doi.org/10.1016/S1352-2310(98)003458, 1999.

Silva, S. J., Heald, C. L., Geddes, J. A., Austin, K. G., Kasibhatla, P. S., and Marlier, M. E.: Impacts of current and projected oil palm plantation expansion on air quality over Southeast Asia, Atmos. Chem. Phys., 16, 10621-10635, https://doi.org/10.5194/acp-1610621-2016, 2016.

Singh, R., Singh, M. P., and Singh, A. P.: Ozone forming potential of tropical plant species of the Vidarbha region of Maharashtra state of India, Urban For. Urban Gree., 13, 814-820, https://doi.org/10.1016/j.ufug.2014.05.007, 2014.

Sodhi, N. S., Koh, L. P., Brook, B. W., and Ng, P. K. L.: Southeast Asian biodiversity: An impending disaster, Trends Ecol. Evol., 19, 654-660, https://doi.org/10.1016/j.tree.2004.09.006, 2004.

Spitters, C. J. T., Toussaint, H. A. J. M., and Goudriaan, J.: Separating the diffuse and direct component of global radiation and its implications for modeling canopy photosynthesis Part I, Components of incoming radiation, Agr. Forest Meteorol., 38, 217-229, https://doi.org/10.1016/0168-1923(86)90060-2, 1986.

Stavrakou, T., Müller, J.-F., Bauwens, M., De Smedt, I., Van Roozendael, M., Guenther, A., Wild, M., and Xia, X.: Isoprene emissions over Asia 1979-2012: impact of climate and land-use changes, Atmos. Chem. Phys., 14, 4587-4605, https://doi.org/10.5194/acp-14-4587-2014, 2014.

Stockwell, W. R., Kirchner, F., Kuhn, M., and Seefeld, S.: A new mechanism for regional atmospheric chemistry modeling, J. Geophys. Res., 102, 25847-25879, https://doi.org/10.1029/97JD00849, 1997.

Stone, D., Evans, M. J., Edwards, P. M., Commane, R., Ingham, T., Rickard, A. R., Brookes, D. M., Hopkins, J., Leigh, R. J., Lewis, A. C., Monks, P. S., Oram, D., Reeves, C. E., Stewart, D., and Heard, D. E.: Isoprene oxidation mechanisms: measurements and modelling of $\mathrm{OH}$ and $\mathrm{HO} 2$ over a South-East Asian tropical rainforest during the OP3 field campaign, Atmos. Chem. Phys., 11, 6749-6771, https://doi.org/10.5194/acp-11-6749-2011, 2011.

Suratman, M. N., Bull, G. Q., Leckie, D. G., Lemay, V. M., Marshall, P. L., and Mispan, M. R.: Prediction models for estimating the area, volume, and age of rubber (Hevea brasiliensis) plantations in Malaysia using Landsat TM data, Int. Forest. Rev., 6, 1-12, https://doi.org/10.1505/ifor.6.1.1.32055, 2004.

Surratt, J. D., Chan, A. W. H., Eddingsaas, N. C., Chan, M., Loza, C. L., Kwan, A. J., Hersey, S. P., Flagan, R. C., Wennberg, P. O., and Seinfeld, J. H.: Reactive intermediates revealed in secondary organic aerosol formation from isoprene, P. Natl. Acad. Sci. USA, 107, 6640-6645, https://doi.org/10.1073/pnas.0911114107, 2010.

Thompson, A. M., Tao, W.-K., Pickering, K. E., Scala, J. R., and Simpson, J.: Tropical deep convection and ozone formation, B. Am. Meteorol.
Soc., 78, 1043-1054, https://doi.org/10.1175/1520 0477(1997)078<1043:TDCAOF>2.0.CO;2, 1997.

Tilmes, S., Lamarque, J.-F., Emmons, L. K., Conley, A., Schultz, M. G., Saunois, M., Thouret, V., Thompson, A. M., Oltmans, S. J., Johnson, B., and Tarasick, D.: Technical Note: Ozonesonde climatology between 1995 and 2011: description, evaluation and applications, Atmos. Chem. Phys., 12, 74757497, https://doi.org/10.5194/acp-12-7475-2012, 2012.

Tsigaridis, K. and Kanakidou, M.: Secondary organic aerosol importance in the future atmosphere, Atmos. Environ., 41, 46824692, https://doi.org/10.1016/j.atmosenv.2007.03.045, 2007.

Tsigaridis, K., Daskalakis, N., Kanakidou, M., Adams, P. J., Artaxo, P., Bahadur, R., Balkanski, Y., Bauer, S. E., Bellouin, N., Benedetti, A., Bergman, T., Berntsen, T. K., Beukes, J. P., Bian, H., Carslaw, K. S., Chin, M., Curci, G., Diehl, T., Easter, R. C., Ghan, S. J., Gong, S. L., Hodzic, A., Hoyle, C. R., Iversen, T., Jathar, S., Jimenez, J. L., Kaiser, J. W., Kirkevåg, A., Koch, D., Kokkola, H., Lee, Y. H., Lin, G., Liu, X., Luo, G., Ma, X., Mann, G. W., Mihalopoulos, N., Morcrette, J.-J., Müller, J.-F., Myhre, G., Myriokefalitakis, S., Ng, N. L., O'Donnell, D., Penner, J. E., Pozzoli, L., Pringle, K. J., Russell, L. M., Schulz, M., Sciare, J., Seland, Ø., Shindell, D. T., Sillman, S., Skeie, R. B., Spracklen, D., Stavrakou, T., Steenrod, S. D., Takemura, T., Tiitta, P., Tilmes, S., Tost, H., van Noije, T., van Zyl, P. G., von Salzen, K., Yu, F., Wang, Z., Wang, Z., Zaveri, R. A., Zhang, H., Zhang, K., Zhang, Q., and Zhang, X.: The AeroCom evaluation and intercomparison of organic aerosol in global models, Atmos. Chem. Phys., 14, 10845-10895, https://doi.org/10.5194/acp-1410845-2014, 2014.

Unger, N.: On the role of plant volatiles in anthropogenic global climate change, Geophys. Res. Lett., 41, 8563-8569, https://doi.org/10.1002/2014GL061616, 2014.

Unger, N., Bond, T. C., Wang, J. S., Koch, D. M., Menon, S., Shindell, D. T., and Bauer, S.: Attribution of climate forcing to economic sectors, P. Natl. Acad. Sci. USA, 107, 3382-3387, https://doi.org/10.1073/pnas.0906548107, 2010.

Unger, N., Harper, K., Zheng, Y., Kiang, N. Y., Aleinov, I., Arneth, A., Schurgers, G., Amelynck, C., Goldstein, A., Guenther, A., Heinesch, B., Hewitt, C. N., Karl, T., Laffineur, Q., Langford, B., McKinney, K. A., Misztal, P., Potosnak, M., Rinne, J., Pressley, S., Schoon, N., and Serça, D.: Photosynthesis-dependent isoprene emission from leaf to planet in a global carbonchemistry-climate model, Atmos. Chem. Phys., 13, 1024310269, https://doi.org/10.5194/acp-13-10243-2013, 2013.

USDA: Indonesia: Rising global demand fuels palm oil expansion, Commodity Intelligence Report, United States Department of Agriculture Foreign Agricultural Service, 2010.

USDA: Oilseeds: World markets and trade, United States Department of Agriculture Foreign Agricultural Service, 2017.

van der Werf, G. R., Randerson, J. T., Giglio, L., Collatz, G. J., Kasibhatla, P. S., and Arellano Jr., A. F.: Interannual variability in global biomass burning emissions from 1997 to 2004, Atmos. Chem. Phys., 6, 3423-3441, https://doi.org/10.5194/acp-6-34232006, 2006.

van der Werf, G. R., Morton, D. C., DeFries, R. S., Olivier, J. G., Kasibhatla, P. S., Jackson, R. B., Collatz, G. J., and Randerson, J. T.: $\mathrm{CO}_{2}$ emissions from forest loss, Nat. Geosci., 2, 737-738, https://doi.org/10.1038/ngeo671, 2009. 
Vermeulen, S. and Goad, N.: Towards better practice in smallholder palm oil production, Natural Resource Issues Series (No. 5), International Institute for Environment and Development, London, UK, 2006.

Warwick, N. J., Archibald, A. T., Ashworth, K., Dorsey, J., Edwards, P. M., Heard, D. E., Langford, B., Lee, J., Misztal, P. K., Whalley, L. K., and Pyle, J. A.: A global model study of the impact of land-use change in Borneo on atmospheric composition, Atmos. Chem. Phys., 13, 9183-9194, https://doi.org/10.5194/acp-13-9183-2013, 2013.

Weedon, G. P., Balsamo, G., Bellouin, N., Gomes, S., Best, M. J., and Viterbo, P.: The WFDEI meteorological forcing data set: WATCH Forcing Data methodology applied to ERAInterim reanalysis data, Water Resour. Res., 50, 7505-7514, https://doi.org/10.1002/2014WR015638, 2014.

Wilkinson, M. J., Owen, S. M., Possell, M., Hartwell, J., Gould, P., Hall, A., Vickers, C., and Hewitt, C. N.: Circadian control of isoprene emissions from oil palm (Elaeis guineensis), Plant J., 47, 960-968, https://doi.org/10.1111/j.1365313X.2006.02847.x, 2006.

Wolfe, G. M., Kaiser, J., Hanisco, T. F., Keutsch, F. N., de Gouw, J. A., Gilman, J. B., Graus, M., Hatch, C. D., Holloway, J., Horowitz, L. W., Lee, B. H., Lerner, B. M., LopezHilifiker, F., Mao, J., Marvin, M. R., Peischl, J., Pollack, I. B., Roberts, J. M., Ryerson, T. B., Thornton, J. A., Veres, P. R., and Warneke, C.: Formaldehyde production from isoprene oxidation across NOx regimes, Atmos. Chem. Phys., 16, 2597-2610, https://doi.org/10.5194/acp-16-2597-2016, 2016.
Wong, A. Y. H., Tai, A. P. K., and Ip, Y.-Y.: Attribution and statistical parameterization of the sensitivity of surface ozone to changes in leaf area index based on a chemical transport model, J. Geophys. Res.-Atmos., 123, 1883-1898, https://doi.org/10.1002/2017JD027311, 2018.

WRI: CAIT Climate Data Explorer [Electronic database], World Resources Institute, http://cait.wri.org (last access: 25 September 2017), 2015.

Yienger, J. J. and Levy II, H.: Empirical model of global soilbiogenic $\mathrm{NO}_{x}$ emissions, J. Geophys. Res., 100, 11447-11464, https://doi.org/10.1029/95JD00370, 1995.

Yue, X. and Unger, N.: The Yale Interactive terrestrial Biosphere model version 1.0: description, evaluation and implementation into NASA GISS ModelE2, Geosci. Model Dev., 8, 2399-2417, https://doi.org/10.5194/gmd-8-2399-2015, 2015.

Zhang, H., Yee, L. D., Lee, B. H., Curtis, M. P., Worton, D. R., Isaacman-VanWertz, G., Offenberg, J. H., Lewandowski, M., Kleindienst, T. E., Beaver, M. R., Holder, A. L., Lonneman, W. A., Docherty, K. S., Jaoui, M., Pye, H. O. T., Hu, W., Day, D. A., Campuzano-Jost, P., Jimenez, J. L., Guo, H., Weber, R. J., de Gouw, J., Koss, A. R., Edgerton, E. S., Brune, W., Mohr, C., Lopez-Hilfiker, F. D., Lutz, A., Kreisberg, N. M., Spielman, S. R., Hering, S. V., Wilson, K. R., Thornton, J. A., and Goldstein, A. H.: Monoterpenes are the largest source of summertime organic aerosol in the southeastern United States, P. Natl. Acad. Sci. USA, 115, 2038-2043, https://doi.org/10.1073/pnas.1717513115, 2018. 